\title{
Norveç Varlık Fonu Üzerine Bir İnceleme*
}

\section{An Analysis on Norwegian Wealth Fund}

Hüseyin Burak Özgül ${ }^{1}$

\begin{tabular}{l} 
ARTICLE INFO \\
\hline Submitted : 27.05 .2020 \\
Revised : 27.06 .2020 \\
Accepted : 06.07.2020 \\
Available : 24.07.2020 \\
\hline iThenticate similarity \\
score: $6 \%$ \\
\hline JEL classification: \\
F30, G23, G38 \\
\hline Keywords: \\
Sovereign Wealth \\
Funds, The \\
Government Pension \\
Fund-Global, \\
Norwegian Wealth \\
Fund, The Government \\
Petroleum Fund of \\
Norway
\end{tabular}

\section{ARTICLE INFO}

Submitted : 27.05.2020

Available : 24.07.2020 score: $6 \%$

\begin{abstract}
A B S T R A C T
Sovereign wealth funds that emerged in the mid-twentieth century and of which numbers have largely grown since then have become an important issue at the heart of discussions today. Although initially based on commodities such as oil and gas, there are many sovereign wealth funds based on budget, current account surplus, and privatization revenues recently. Sovereign wealth funds based on commodities, however, compose the majority. The Norwegian Wealth Fund has the largest value of assets and is the most known of those. Norway's adventure of sovereign wealth funds began in 1969 with the discovery and processing of oil within the continental shelf. Then, the use of excess revenue from oil was discussed for many years. After these discussions, the Norwegian Wealth Fund was established in 1990 with the name of the Government Petroleum Fund to utilize the income surpluses. The fund, renamed as the Government Pension Fund Global in 2006, has become the largest sovereign wealth fund of all as well as the commodity-based ones today. In this study, the Norwegian Wealth Fund has been analyzed in terms of fund mechanism and organizational structure to provide an insight for Turkey Wealth Fund which is established in 2016 and considered a new Wealth Fund in the world. Particularly good governance, transparency, implementation of a fiscal rule, and a dynamic structure of governance are the main factors behind the development of the fund.
\end{abstract}

Cite this article as: Özgül, H. B. (2020). "Norveç Varlık Fonu Üzerine Bir İnceleme”, International Journal of Public Finance, 5(1), 101-126.

\footnotetext{
* Bu çalışma, yazarın 2019 yılında Antalya'da düzenlenen 34. Uluslararası Maliye Sempozyumu’nda sunduğu "Varlık Fonları: Norveç Örneği" başlıklı bildirisinin düzenlenmiş ve genişletilmiş halidir.

1 Res. Assist., İstanbul University, Department of Public Finance, Turkey, ORCID: 0000-0002-0620-2493, burak.ozgul@istanbul.edu.tr
} 


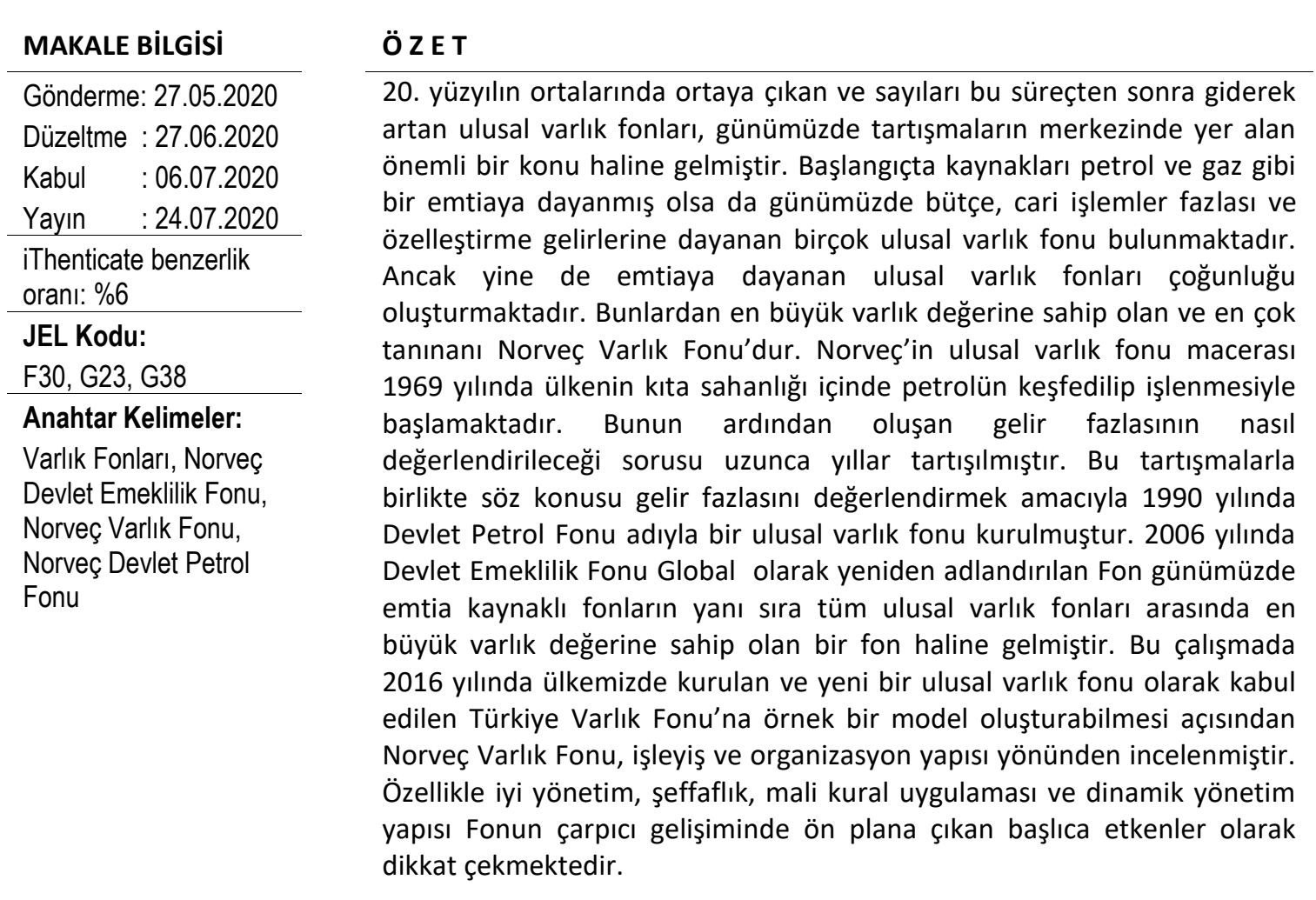

\section{Giriş}

Ulusal Varlık Fonu" (Sovereign Wealth Fund) terimi ilk olarak Andrew Rozanov tarafından 2005 yılında kullanılmıştır. Rozanov bir ülkenin makroekonomisinin, ticaret koşullarının ve bütçe dengesinin iyileştirilmesi ve harcama kısıtlama politikalarının uygulanmasıyla, o ülkede bütçe fazlası ve dış ticaret rezerv fazlalarının biriktiğini belirtmiştir. Bu sebepten söz konusu fazlalıkları yönetmek için yatırım kurumlarının kurulduğunu ve bu kurumlara Ulusal Varlık Fonları adı verilebileceğini ifade etmiştir (Ping \& Chao, 2009: 2).

Ulusal varlık fonlarının 3 temel özelliği bulunmaktadır. Bunlardan ilki devletlerin kontrolüne ve mülkiyetine dayanmasıdır. İkinci özelliği ise ağılıklı olarak yurtdışına yatırım yapmasıdır. Son özelliği ise genelde makroekonomik amaçları gerçekleştirmek için uzun vadeli amaçlar doğrultusunda kurulmasıdır. Söz konusu makroekonomik amaçlardan birisi istikrar ve nesiller arası refahın sağlanmasıdır (IWG, 2008: 27). Bu amaçların yanında bir ülkenin altyapı projelerinin finansmanının sağlanması ve potansiyel üretiminin arttırılması yoluyla o ülkede kalkınmayı sağlamak için kurulmuş olan ve yatırımlarını iç piyasaya yönelten ulusal varlık fonları da bulunmaktadır (AlHassan vd., 2013: 5).

Ulusal Varlık fonlarının varlıkları, ödemeler dengesini sağlamak amacıyla oluşturulan Merkez Bankası rezervlerinden farklıdır. Ayrıca diğer kurum, kuruluş veya fonlarla karıştırılmamalıdır (IWG, 2008: 27). Merkez bankalarının döviz kurundaki dalgalanmaları gidermek için belirli bir miktarda döviz likiditesi bulundurması ve bu 
sebepten rezervlerinin önemli bir kısmını tahvillerde tutması gerekir (Demarolle, 2009: 6). Ulusal varlık fonları ise tahvil ve hisse senedinin yanı sıra, hedge fonlar ve özel sermayeli fonlar gibi yüksek riskli varlıkları içeren çeşitlendirilmiş bir yatırım portföyüne sahiptir (Ping \& Chao, 2009: 6).

Her ne kadar isimlerinde emeklilik fonu geçse de ulusal varlık fonu sınıflandırmalarına giren fonlar emeklilik fonlarından da ayrılmaktadır. Ulusal varlık fonlarının çoğunlukla döviz rezervleri ve ihracat gelirleriyle finanse edilmesine karşılık özellikle kamu emeklilik fonları toplumdaki üyelerin katkılarını barındıran sosyal güvenlik gelirleriyle finanse edilmektedir (Ping \& Chao, 2009: 6). Emeklilik fonlarının gelecekte geri ödeme yükümlülükleri bulunurken, ulusal varlık fonlarının böyle bir yükümlülüğü yoktur (Csoma, 2015: 271).

Ulusal varlık fonlarının finansman kaynakları, yatırım stratejileri, örgütlenme biçimleri, amaçları, coğrafi konumları gibi birçok açıdan sınıflandırması mümkündür. Bunların arasından finansman kaynakları açısından sınıflandırma ile amaçları açısından sınıflandırma daha fazla kullanılmaktadır. Finansman kaynakları açısından sınıflandırmaya göre ulusal varlık fonları emtia (commodity) ve emtia dışı (noncommodity) kaynaklı olmak üzere ikiye ayrılmaktadır (Keller, 2008: 337). Emtia kaynaklı ulusal varlık fonları genellikle petrol, doğal gaz, bakır, fosfat, elmas gibi yenilenemeyen doğal kaynaklardan elde edilen gelirlerle kurulmaktayken; emtia dışı kaynağı olan ulusal varlık fonları bütçe fazlası, cari işlemler fazlası ile özelleştirme gelirleri gibi kaynaklar vasıtasıyla kurulmaktadır (Özgül, 2018: 27). Bu kapsamda Birleşik Arap Emirlikleri, Kuveyt, Katar gibi körfez ülkeleri ile Norveç ve Rusya Federasyonu petrol ihracatı sonucu oluşan gelirlerle; Şili, Botsvana, Kiribati gibi ülkeler bakır, elmas, fosfat gibi doğal kaynak gelirleriyle; Fransa, Avustralya, Yeni Zelanda gibi ülkeler sosyal güvenlik primleriyle; Singapur, Güney Kore ve Çin Halk Cumhuriyeti gibi ülkeler ise ihracat kaynaklı cari işlemler fazlası, döviz rezervleri, özelleştirme ve tasarruf politikalarıyla elde ettiği gelirlerle fonlarını kurmuşlardır (Yalçıner ve Sürekli, 2015: 3).

Amaçları açısından sınıflandırmaya göre ulusal varlık fonları; İstikrar Fonları, Tasarruf Fonları, Rezerv Yatırım Fonları, Kalkınma Fonları ve Emeklilik Rezerv Fonları olmak üzere beşe ayrılmaktadır ${ }^{2}$. İstikrar Fonları; ekonomiyi finansal dalgalanmalar ve dış şoklardan korumak için, Tasarruf Fonları; servetin nesiller arası dağılımını sağlamak için, Rezerv Yatırım Fonları; rezerv fazlalarını yüksek getirili araçlarda değerlendirmek için, Kalkınma Fonları; altyapı yatırımlarının finansmanını sağlamak ve üretimi artırmak için, Emeklilik Rezerv Fonları ise gelecekteki emeklilik ödemelerine kaynak oluşturmak için kurulmaktadır (Al-Hassan vd.,2013: 5-6).

Ulusal varlık fonları 21. yüzyıldan itibaren dünyada önemli bir finansal konu olarak ortaya çıksa ve adlandırılsa da bu fonların tarihi daha eskilere dayanmaktadır. Literatür incelendiğinde IMF'in tanımlarına uyan ilk çağdaş ulusal varlık fonunun; petrol geliri fazlalarını yönetmek için 1953 yılında Kuveyt'te kurulan fon olduğu belirtilmektedir (Alhashel, 2015: 2).

\footnotetext{
${ }^{2}$ Bu sınıflandırma çeşitli yayınlarda ikili, üçlü ve dörtlü olarak gösterilebilmektedir (Özgül, 2018: 28).
} 
1950'li yıllarda sayıları çok az olan ulusal varlık fonlarının, 90'lı yılların sonundan itibaren sayılarında büyük bir artış olmuş ve söz konusu fonlar bütün dünyaya yayılmıştır. Bu artışın ana nedenleri olarak 1970'li yıllardaki petrol krizinden sonra büyük petrol ihracatçısı ülkelerin petrol kaynaklarının tükenmesi endişesiyle ulusal varlık fonlarına yönelmesi (Sun vd., 2014: 655) ve 1997-1998 yıllarında meydana gelen Asya Krizi'nden sonra Doğu Asya Ülkeleri'nin yeni yatırım araçları aramaya yönelerek ulusal varlık fonlarına başvurması gösterilebilir (Aykın, 2011: 9).

Illk olarak 2005 yılındaki adlandırımalarının ardından ulusal varlık fonlarının kavramsal bütünlüğünü ve sınırlarını tanımlayan birçok çalışma ortaya çıkmıştır. Söz konusu çalışmalarda genellikle varlık fonlarının finansal sisteme etkisi ile şeffaflık sorunları irdelenmiştir (Johnson, 2007; Truman, 2007; Beck \& Fidora, 2008; Aizenman \& Glick, 2009; Balin, 2009). 2007-2008 yılları ulusal varlık fonlarının uluslararası düzeyde güvenlik sorunlarının tartışıldığı yıllar olmuş, hükümetler ulusal varlık fonlarına karşı kısıtlama önlemleri almış ve IMF, OECD, IWG (Uluslararası Varlık Fonu Çalışma Grubu) gibi küresel grupların yardımı ile Santiago İlkeleri olarak adlandırılan bir dizi önlemler oluşturulmuştur (IFSWF, 2020). Bu güvenlik önlemlerinin oluşturulmasından sonraki yıllarda yapılan çalışmalar ulusal ve uluslararası güvenlik sorunlarından ziyade mevcut ulusal varlık fonlarının nasıl yönetildiği, nasıl en iyi şekilde yönetilebileceği ve yatırım stratejilerinin nasıl olması gerektiği gibi konular üzerine yoğunlaşmıştır (Truman, 2009; Jen, 2009; Truman, 2010; Balding, 2011; Kunzel vd., 2011; Bernstein vd., 2013; Clark vd., 2013; Al-Hassan vd., 2013; Alhashel, 2015).

Türkiye'de bir varlık fonu kurulmadan önce yapılan ilk çalışmalar, uluslararası alanda olduğu gibi ulusal varlık fonlarının şeffaflığı, düzenlenmesi ve sermaye piyasalarına etkileri üzerine yapılmış daha sonraki çalışmalarda ulusal varlık fonlarının Türkiye açısından uygulanabilirliği tartışıımıştır (Akbulak \& Akbulak, 2008; Hacıhasanoğlu \& Soytaş, 2010; Şanlı, 2010; Aykın, 2011; Dedekoca, 2012; Bayar \& Yıldırım, 2013; Yalçıner \& Sürekli, 2015).

Bu çalışmaların ardından 26.08.2016 tarihinde Resmî Gazetede yürürlüğe giren 6741 sayılı kanunla Türkiye Varlık Fonu (TVF) kurulmuştur. Fonun kuruluş amacı kamu varlıklarında değer artışı sağlayarak ekonomik büyümeye katkıda bulunmak, sermaye piyasalarının derinleşmesini sağlamak, stratejik önemdeki sektörleri geliştirmek ve ülkedeki yatırımları artırmaktır (TVF Faaliyet Raporu, 2017: 8). TVF'nin kuruluşunun ardından yapılan çalışmalar hem dünyadaki ulusal varlık fonu örneklerini hem Türkiye Varlık Fonu'nu incelemeye yönelmiştir (Karagöl \& Koç, 2016; Kayıran, 2016; Yazıcı, 2017; Konukman \& Şimşek, 2017; Yereli \& Yaman, 2017; Karagenç, 2017; Selçuk \& Savaşan, 2017; Akyol \& Hayaloğlu, 2017; Nas, 2017; Uysal Şahin, 2017; Güçlü, 2018). Bunların yanında Türkiye Varlık Fonu'na yön göstermesi açısından Çin Halk Cumhuriyeti, Singapur gibi ülkelerin fonlarını inceleyen yayınlar da bulunmaktadır (Şimşek, 2017; Durdu, 2018).

Dünya ülkeleri arasında uygulama örnekleri incelendiğinde varlık değeri ve şeffaflık açısından en ön sırada gösterilen ve dünyanın en büyük ulusal varlık fonu olan Norveç Varlık Fonu'nun, Türkiye Varlık Fonu için iyi bir uygulama örneği olabileceği düşünülmektedir. Bu nedenle çalışmada, Türkiye Varlık Fonu'nun kuruluş amacına 
uygun olarak, fonun organizasyonu ve işleyişine katkı sağlayacağı düşünülen Norveç Varlık Fonu, organizasyon yapısı, dünyadaki ulusal varlık fonları içindeki konumu ve yatırım stratejileri açısından, kurulduğu ilk yıldan günümüze detaylı bir şekilde incelenecektir.

\section{Dünyada Ulusal Varlık Fonları}

Günümüzde 57 ülkede toplam 91 ulusal varlık fonu bulunmaktadır. Söz konusu fonların 13'ü ABD yönetiminde, 7 tanesi Çin Halk Cumhuriyeti yönetiminde, 4 tanesi Birleşik Arap Emirlikleri yönetimindedir. Birçok ülkede birden fazla ulusal varlık fonu bulunsa da Tablo 1'den de görülebileceği üzere en büyük varlık değerine sahip ulusal varlık fonu Norveç Varlık Fonu'dur (SWFI Institute, 2020a).

Tablo 1. Dünyadaki En Büyük 15 Ulusal Varlık Fonu (2020)

\begin{tabular}{|l|l|l|r|}
\hline & Fon Adı & Ülke & Toplam Değer (\$) \\
\hline 1 & Norway Government Pension Fund Global & Norveç & 1.186 .670 .000 .000 \\
\hline 2 & China Investment Corporation & Çin Halk Cumhuriyeti & 940.604 .000 .000 \\
\hline 3 & Abu Dhabi Investment Authority & Birleşik Arap Emirlikleri & 579.621 .120 .000 \\
\hline 4 & Kuwait Investment Authority & Kuveyt & 533.650 .000 .000 \\
\hline 5 & Hong Kong Monetary Authority Investment Portfolio & Çin Halk Cumhuriyeti & 528.054 .000 .000 \\
\hline 6 & GIC Private Limited & Singapur & 440.000 .000 .000 \\
\hline 7 & SAFE Investment Company & Çin Halk Cumhuriyeti & 417.844 .700 .460 \\
\hline 8 & Temasek Holdings & Singapur & 375.383 .000 .000 \\
\hline 9 & National Council for Social Security Fund & Çin Halk Cumhuriyeti & 324.996 .000 .000 \\
\hline 10 & Public Investment Fund & Suudi Arabistan & 320.000 .000 .000 \\
\hline 11 & Qatar Investment Authority & Katar & 295.200 .000 .000 \\
\hline 12 & Investment Corporation of Dubai & Suudi Arabistan & 239.379 .000 .000 \\
\hline 13 & Mubadala Investment Company & Birleşik Arap Emirlikleri & 232.137 .000 .000 \\
\hline 14 & Turkey Wealth Fund & Türkiye & 222.151 .000 .000 \\
\hline 15 & National Welfare Fund & Rusya & 165.380 .000 .000 \\
\hline
\end{tabular}

Kaynak: SWFI Institute, https://www.swfinstitute.org/sovereign-wealth-fund-rankings/ (Erişim Tarihi: 18.05.2020)

Ulusal varlık fonlarının toplam varlık değeri 2020 yılında yaklaşık 8,189 trilyon dolardır. Bölgesel olarak incelendiğinde Afrika, Avrupa ve Orta Doğu'da 11'er ülkede, Asya'da 10 ülkede, Amerika'da 9 ülkede, Okyanusya'da ise 5 ülkede ulusal varlık fonu bulunmaktadır. Ancak Şekil 1'den de görülebileceği üzere varlık değeri bakımından Asya ve Ortadoğu'da bulunan ulusal varlık fonlarının toplam değere oranı \%75.1'dir. Bir 
diğer ifadeyle 2 bölgedeki 21 ülkenin ulusal varlık fonlarının yarattığı değer toplam değerin 3/4'ünü oluşturmaktadır.

\section{Şekil 1. Ulusal Varlık Fonlarının Bölgesel Dağılımı (Toplam Değer Bakımından \%)}

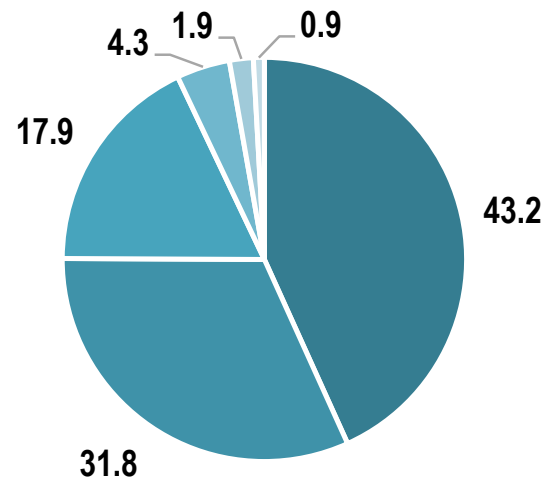

- Asya

- Orta Doğu

- Avrupa

- Amerika

- Okyanusya

Afrika

Kaynak: SWFI Institute, https://www.swfinstitute.org/sovereign-wealth-fund-rankings/ (Erişim Tarihi: 18.05.2020)

Bu dağılım ülkeler açısından incelendiğinde en büyük varlık değerine sahip olan dört ülkenin toplam değerin \%62.7'sini oluşturduğu görülmektedir (Şekil 2). Ancak Çin Halk Cumhuriyeti yönetiminde 7, Birleşik Arap Emirlikleri'nde 4, Singapur'da 2 varlık fonu olmasına karşılık Norveç, tek ulusal varlık fonu ile toplam değerin \%14.5'ini sağlamaktadır.

\section{Şekil 2. Ulusal Varlık Fonlarının Ülkelere Göre Dağılımı (Toplam Değer Bakımından \%)}

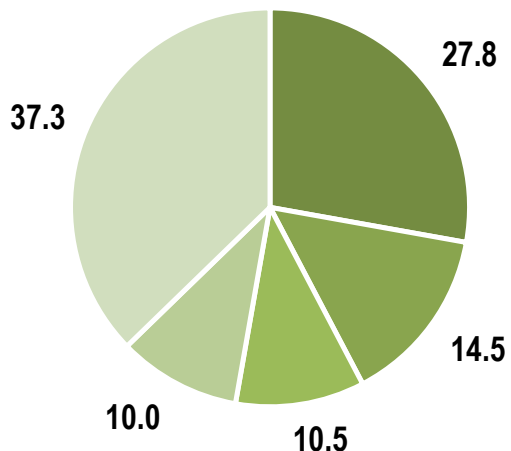

- Çin Halk Cumhuriyeti

- Norveç

- Birleşik Arap Emirlikleri

¿ Singapur

- Diğer

Kaynak: SWFI Institute, https://www.swfinstitute.org/sovereign-wealth-fund-rankings/ (Erişim Tarihi: 18.05.2020) 


\section{Norveç Devlet Emeklilik Fonu Global (GPFG)}

Ulusal Varlık Fonu Enstitüsü (SWFI) verilerine göre 2020 yılı itibariyle 1.1 trilyondan yüksek varlık değeri olan Government Pension Fund Global (GPFG) dünyanın en büyük ulusal varlık fonudur. Söz konusu Fon, dünyada yaygın olarak şeffaf ve iyi yönetilen bir fon olarak tanımlanmakta, etik ve sosyal açıdan sorumlu yatırım girişimlerinin ön saflarında yer almaktadır (Clark \& Monk, 2010: 14).

\subsection{Tarihsel Gelişim}

Norveç Varlık Fonu, ülke içindeki petrol kaynaklarının çıkarılmasıyla doğrudan bağlantılıdır. Norveç'te petrol ilk olarak 1969 yılında Kuzey Denizi'nde keşfedilmiş ve iki yıl sonra işlenmeye başlanmıştır. 1990'lara gelindiğinde petrolün üretiminden önemli bir miktarda gelir birikmiştir ${ }^{3}$. Norveç Hükümeti giderek artan petrol gelirlerinin uzun vadeli yönetimini desteklemek için bir araç olarak Devlet Petrol Fonu'nu (Government Petroleum Fund) kurmuştur. Söz konusu Fon; Norveç Parlamentosu tarafından 1990 yılında Devlet Petrol Fonu Yasası'nın (Government Petroleum Fund Law) kabul edilmesiyle kurulmuştur (Backer, 2009: 132) ${ }^{4}$.

Fonun kurulmasındaki en önemli sebeplerden biri merkezi yönetim bütçesi içindeki petrol gelirlerinin nasıl kullanıldığının daha belirgin hale getirilmesidir. Özellikle petrol gelirlerindeki dalgalanmalardan dolayı kamu finansmanında uzun vadede oluşabilecek zorluklarla başa çıkmak için söz konusu gelirlerin bir fonda toplanarak değerlendirilmesi amaçlanmıştır (Norges Bank, 1998: 4). Uzun Vadeli Programlar ve birçok raporda ülkenin asıl zenginlik kaynağının beşerî sermaye olduğu belirtilerek gelecek dönemlerle ilgili projeksiyonlar yapılmıştır. Bu raporlarda petrol gelirlerinin zamanla tükeneceği ve gelecekteki emeklilik ödemelerini karşılayamayacağı öngörülmüştür (Scancke, 2003: 316-318). Bu vasıtayla gelecek yıllardaki nüfus artışının bir sonucu olarak oluşabilecek sosyal güvenlik harcamalarını finanse etmek ve gelecek

\footnotetext{
3 Petrolün bulunmasından sonraki ilk yıllarda hükümet için muazzam bir gelir kaynağı meydana gelmiştir. Söz konusu kaynağın gelecekte kullanılması için mevzuat çalışmaları yürütülürken elde edilen gelirin büyük bir kısmı harcanmıştır. Bu harcamaların bir kısmı yol, köprü, ücretsiz sağlık ve yükseköğretim gibi alanlara harcansa da yapılan diğer harcamalar uzun vadeli büyüme için daha az yararlı olmuştur. Örneğin gemi inşası gibi ölmekte olan sektörlere harcamalar yapılmış, yeni girişimlere yönelik fonlar etkin kullanılamamıştır. Hükümetin petrol gelirlerini bu şekilde harcaması 1980'lerin sonunda petrol fiyatları düştüğünde kamu ve özel sektör finansmanında sıkıntılar meydana getirmiştir. 1985'te yaklaşık 11.2 milyar dolar (Norveç'in GSYH'sinin yaklaşık \%20'si) olan petrol gelirleri 1988'de 2.4 milyar dolara düşmüştür. Bunun sonucunda kamu harcamaları azaltılmış, krediler sıkılaştırılmış akabinde bu durum vatandaşlar tarafından bir iflas dalgası getirerek birçok bankanın batmasına sebebiyet vermiştir. Hollanda Hastalığı olarak da adlandırılan ani zenginleşmenin ülkenin ekonomisi üzerindeki olumsuz etkisini engellemek için ülkede varlık fonu kurulması fikri benimsenmiştir (Bernstein vd., 2013: 222-223).

4 Petrol fonu oluşturma fikri ilk olarak 1983 yılında Tempo Komitesi tarafından ortaya atılmış daha sonra Norveç hükümeti tarafından 1986 yılının bahar aylarında yayınlanan Uzun Vadeli Programda desteklenmiştir (Norwegian Ministry of Finance, 2013: 7).
} 
kuşaklara fayda sağlamak için uzun vadeli bir zenginlik kaynağının oluşturulması hedeflenmiştir (Legislative Council Secretariat, 2014: 1).

\section{Grafik 1. Norveç Devlet Emeklilik Fonu-Global'in Gelişimi (1998-2020)}

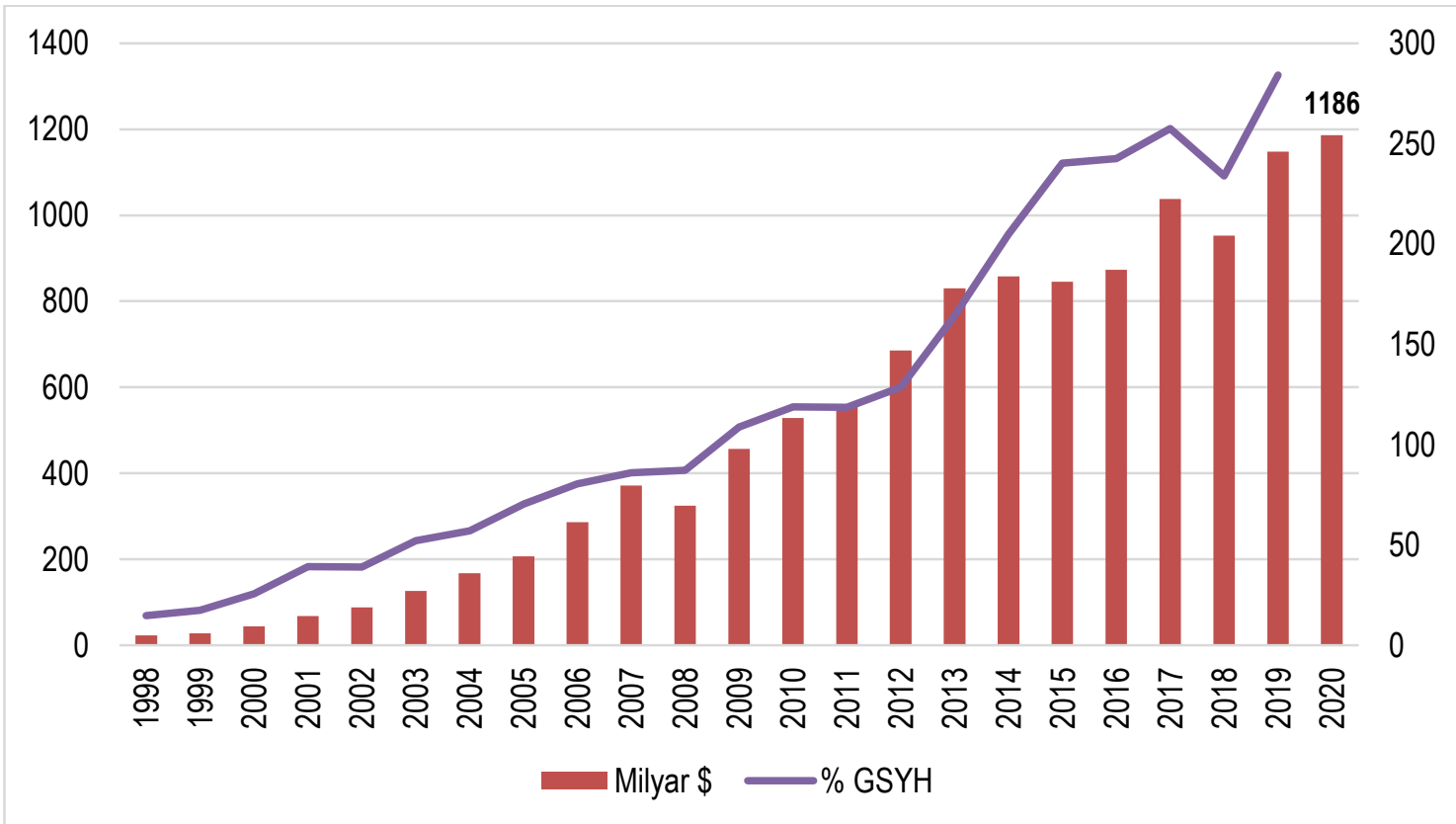

Kaynak: Norges Bank, https://www.nbim.no/, Statistics Norway, https://www.ssb.no/en (Erişim Tarihi: 18.05.2020)

Fonun kurulduğu yıl olan 1990 ile 1995 yılları arası Fona transfer yapılamamıştır. Çünkü 1990'ların ilk yarısında ülkedeki durgunluk nedeniyle bütçe fazlası elde edilememiştir. Bu süreçten sonra ilk bütçe fazlası 1995 yılında verilmiş ve bu yılın bütçe fazlasından söz konusu Fona 1996 yılında ilk sermaye transferi gerçekleştirilmiştir (Skancke, 2003: 318).

2006 yilında Devlet Emeklilik Fonu (The Government Pension Fund) olarak yeniden adlandırılan fon (Clark \& Monk, 2010: 14), ilk sermaye transferini (7.2 milyar dolar) aldığı 1996 yılından günümüze giderek büyümüş ve 2020 yılında 1.1 trilyon dolardan yüksek varlık değeri ile dünyanın en büyük ulusal varlık fonu haline gelmiştir (SWFI Institute, 2020a). Ayrıca Fonun varlık değeri 1998'de Norveç GSYH'sinin \%14.8'ine karşılık gelirken 2019 yılı sonunda \%284'üne karşılık gelmektedir (Grafik 1).

Kişi başına düşen fon payı incelendiğinde Grafik 2'den de görülebileceği gibi başlangıçta 5.190 dolar olan pay 2020 yılı şubat ayı verilerine göre 220.513 dolara yükselmiştir. Bir diğer ifadeyle günümüzde Norveç'te, varlık fonundan kişi başına 220.513 dolar varlık payı düşmektedir. Bununla birlikte Norveç nüfusu 2020 yılında 1998 yılına göre \%21 artış göstermiştir. 


\section{Grafik 2. Norveç'te Kişi Başına Düşen Fon Miktarı (1998-2020) (\$)}

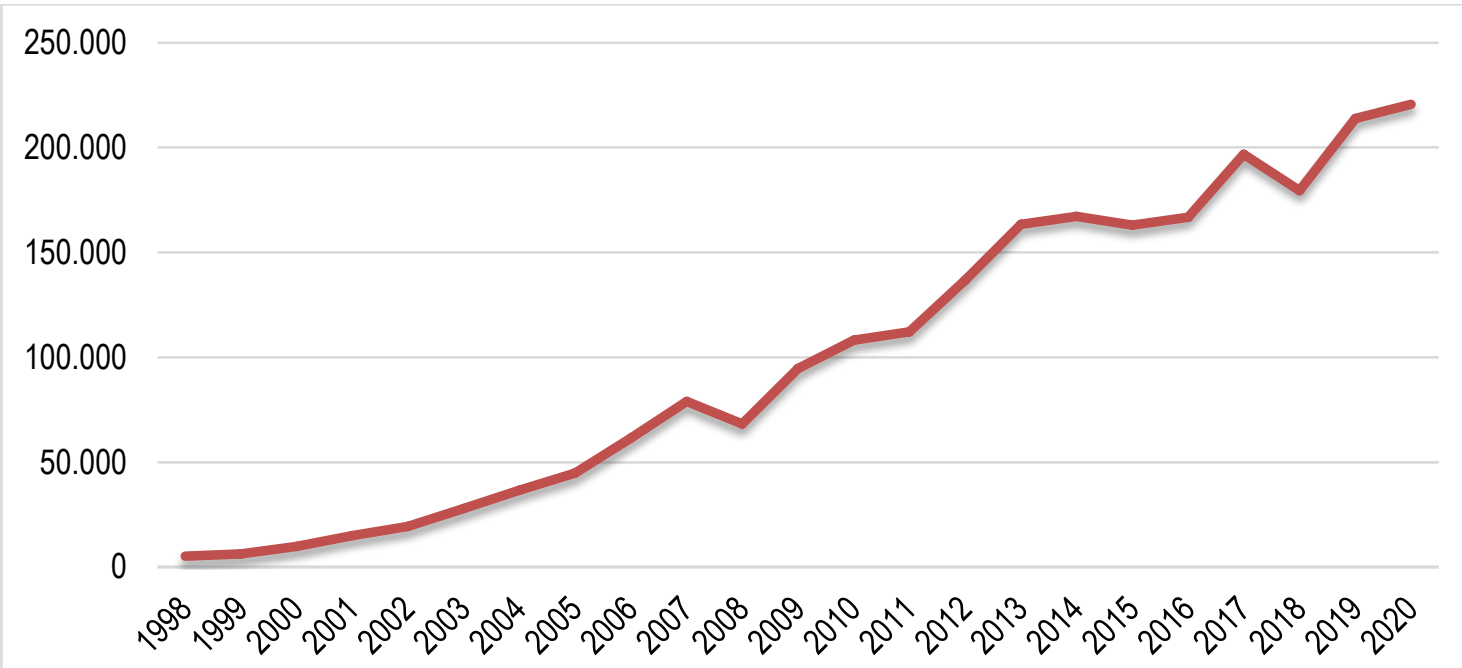

Kaynak: Norges Bank, World Bank Nüfus İstatistikleri, Statistics Norway, https://www.ssb.no/en/ befolkning/statistikker/folkemengde/aar-per-1-januar, (Erişim Tarihi: 19.05.2020).

\subsection{Organizasyon Yapısı}

Günümüzdeki haliyle Norveç Varlık Fonu (The Government Pension Fund), Devlet Emeklilik Fonu-Global (the Government Pension Fund Global) ve Devlet Emeklilik Fonu-Norveç'ten (the Government Pension Fund Norway) oluşmaktadır (Government Pension Fund Act, 2020). Devlet Emeklilik Fonu-Norveç, Ulusal Sigorta Programı Fonu'nu (Folketrygdfondet) kapsamakta ve daha çok ulusal düzeyde faaliyet göstermektedir (Norwegian Ministry of Finance, 2006: 5-6). Bununla birlikte dünyada tanınan, yurtdışına yatırımlar yaparak ulusal varlık fonu özelliği gösteren ve çalışmanın asıl konusunu oluşturan fon Devlet Emeklilik Fonu-Global'dir (GPFG) ${ }^{5}$.

GPFG'nin kendi yönetim kurulu veya idari personeli yoktur. GPFG kanuna göre Maliye Bakanlığı tarafından yönetilmektedir. Fonun idaresi 3 bölüme ayrılmıştır.

- Illk bölüm genel politika oluşturulmasını içerir. Bu işlev Maliye Bakanlığına aittir. Maliye Bakanlığı, fonun yatırım stratejileri ile birlikte etik ve kurumsal yönetim ilkelerini belirlemekte ve operasyonel yönetimini takip etmektedir (Norwegian Ministry of Finance, 2006: 6).

- İkinci bölüm ise operasyonel yönetimdir. Fonun operasyonel yönetimi Norges Bank'a (Norveç Merkez Bankası) devredilmiştir. Bu kapsamda görev paylaşımını

\footnotetext{
5 Norveç Varlık Fonu 1990-2006 arasında Devlet Petrol Fonu olarak faaliyetlerini sürdürmüş, 2006 yılında Ulusal Sigorta Programı Fonunu kapsayan Devlet Emeklilik Fonu-Norveç ile Devlet Petrol Fonu'nun devamı olan Devlet Emeklilik Fonu-Global'in birleşmesiyle Devlet Emeklilik Fonu adını almıştır.
} 
düzenlemek için Maliye Bakanlığı ile Norveç Merkez Bankası arasında bir yönetim anlaşması imzalanmıştır (Bkz. Şekil 3) (Norges Bank, 2008: 6).

\section{Şekil 3. GPFG'nin Organizasyon Yapısı}

Stortinget (Norveç Parlamentosu)

- Norveç Varlık Fonu Yasas
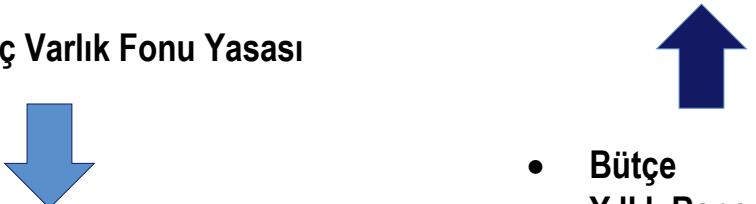

- Bütçe

- Yıllık Rapor

\section{Maliye Bakanlığı}

- Yönetim Görevi

- Genel Politika

- Ek Hükümler

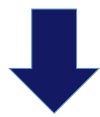

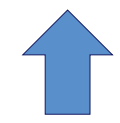

- Yönetim Anlaşması

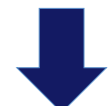

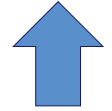

- Çeyrek ve Yıllık Raporlar

- Yatırım Stratejisi Önerisi

\section{Norges Bank (Norveç Merkez Bankası)}

Kaynak: Norges Bank, 2008: 7.

Fonun operasyonel yatırım kararlarının, yatırım yapılan piyasalarla daha uyumlu olabilmesi için yönetim yapısının esnek olması gerekmektedir. Bu yüzden GPFG'nin operasyonel yönetiminin Maliye Bakanlığı tarafından ayrıntılı bir şekilde düzenlenmesi ve yönetilmesi mümkün değildir. Bakanlığın düzenleme yetkisi, yalnızca genel yatırım stratejisi ve sınırları ifade eder. Norges Bank, yatırım kararlarını Bakanlıktan bağımsız olarak almakla görevlidir. Norges Bank'ta yatırım stratejilerini kabul etme ve diğer önemli işler için sorumluluk Yönetim Kuruluna ${ }^{7}$ (Executive Board) aittir. Günlük işlemler ise Norges Bank Yatırım Yönetimi (Norges Bank Investment Management) birimine verilmiştir (Norwegian Ministry of Finance, 2018: 58). Bu kapsamda Norges Bank Yatırım Yönetimi (NBIM) Başkanı, Norges Bank Müdürüne aylık olarak rapor vermekte ancak Merkez Bankasının genel para politikası konusundaki iç tartışmalarında yer almamaktadır (Skancke, 2003: 330).

${ }^{6}$ Koordinasyonu sağlamak için en az üç ayda bir olmak şartıyla Maliye Bakanlığı ile Norveç Merkez Bankası arasında toplantılar yapılmaktadır (Norwegian Ministry of Finance, 2019a: 23).

7 Yönetim kurulu 1 başkan, 2 başkan yardımcısı ve 6 dış üyeden oluşmaktadır. Kurul GPFG'nin yönetiminin verimli ve etkin bir şekilde düzenlenmesini sağlar, GPFG'nin yurtdışı ofislerinin kuruluşuna ve faaliyetlerinin genel kapsamına karar verir (Norwegian Ministry of Finance, 2019a: 2). 
- Fon idaresinin üçüncü bölümü ise denetimdir. Bu kapsamda Parlamentodan iç ve dış yöneticilere kadar çeşitli yönetim düzeyleri arasında açık bir yetki paylaşımı bulunmaktadır. 'den de görülebileceği üzere sistemde görevler ve yetkiler alta doğru devredilirken; performans ve risk yukarı doğru raporlanmaktadır. Her düzeyin bir alt biriminden raporlar alan ve bu birimi denetleyen kendi denetim birimi vardır. Bu ilkenin istisnası, Norges Bank Yönetim Kurulunun Parlamento tarafından atanan Denetim Kurulu (The Supervisory Council) ${ }^{8}$ denetimine tabi olmasıdır (Norwegian Ministry of Finance, 2019b: 18). Denetim Kurulu, tüm banka işlemlerine erişim hakkına sahiptir. Ayrıca yıllık hesapları kabul eder, bütçeyi onaylar ve dış denetim görevini yürütecek dış denetçiyi seçer. Kurul, Parlamentoya yılda en az bir kere denetim raporu sunar ve bu raporların bir örneğini Maliye Bakanlığına gönderir (The Supervisory Council, 2020).

İç denetim görevi Yönetim Kurulu adına Norges Bank İç Denetim Birimi tarafından gerçekleştirilir. Varlık yönetimi ile ilgili iç denetim işlevi ise Uygunluk ve Kontrol Birimi tarafından yürütülmektedir. Bu birim gerektiğinde bağımsız olarak Yönetim Kuruluna rapor verme yetkisine sahiptir (Norwegian Ministry of Finance, 2017: 9).

Norges Bank kamuoyunu da Fon yönetimi konusunda bilgilendirmektedir. Banka bu doğrultuda ulusal varlık fonunun yönetimi hakkında ayrıntılı yıllık raporlar sunmaktadır ${ }^{9}$. Söz konusu halka açık raporlar, fonun nasıl yönetildiğini açıklamakta ve fonun yatırım yaptığı şirketlerin listesini içermektedir. Bu raporlar ayrıca yönetimin arkasındaki yatırım felsefesi, dış yöneticilerin seçilme süreci gibi bilgileri de içermektedir. Ek olarak Banka, ana getiri ve maliyet verilerini içeren üç aylık raporlar da sunmaktadır $^{10}$. Bütün bunların dışında Banka, Denetim Kurulu tarafından atanan bağımsız bir dış denetçi tarafından da denetlenmektedir. Söz konusu denetimin raporları da halka açıktır ve Bankanın raporları gibi internette yayımlanmaktadır (Skancke, 2003: 328-329).

\footnotetext{
84 yıllık dönem için seçilen 15 üyesi vardır.

9 Bu raporlar Muhasebe Kanunu hükümlerine göre hazırlanır ve mali yılın bitiminden itibaren en geç üç ay içinde Yönetim Kurulu tarafından onaylanır (Regulation on the Financial Reporting of Norges Bank, 2017: 2).

${ }^{10}$ Bu raporlar Uluslararası Finansal Raporlama Standartlarına (IFRS) göre hazırlanmaktadır. Söz konusu raporlara ilişkin denetim raporu ise çeyreğin sonundan itibaren en az iki ay içinde sunulmaktadır (Regulation on the Financial Reporting of Norges Bank, 2017: 5).
} 


\section{Şekil 4. Fonun Denetimi}

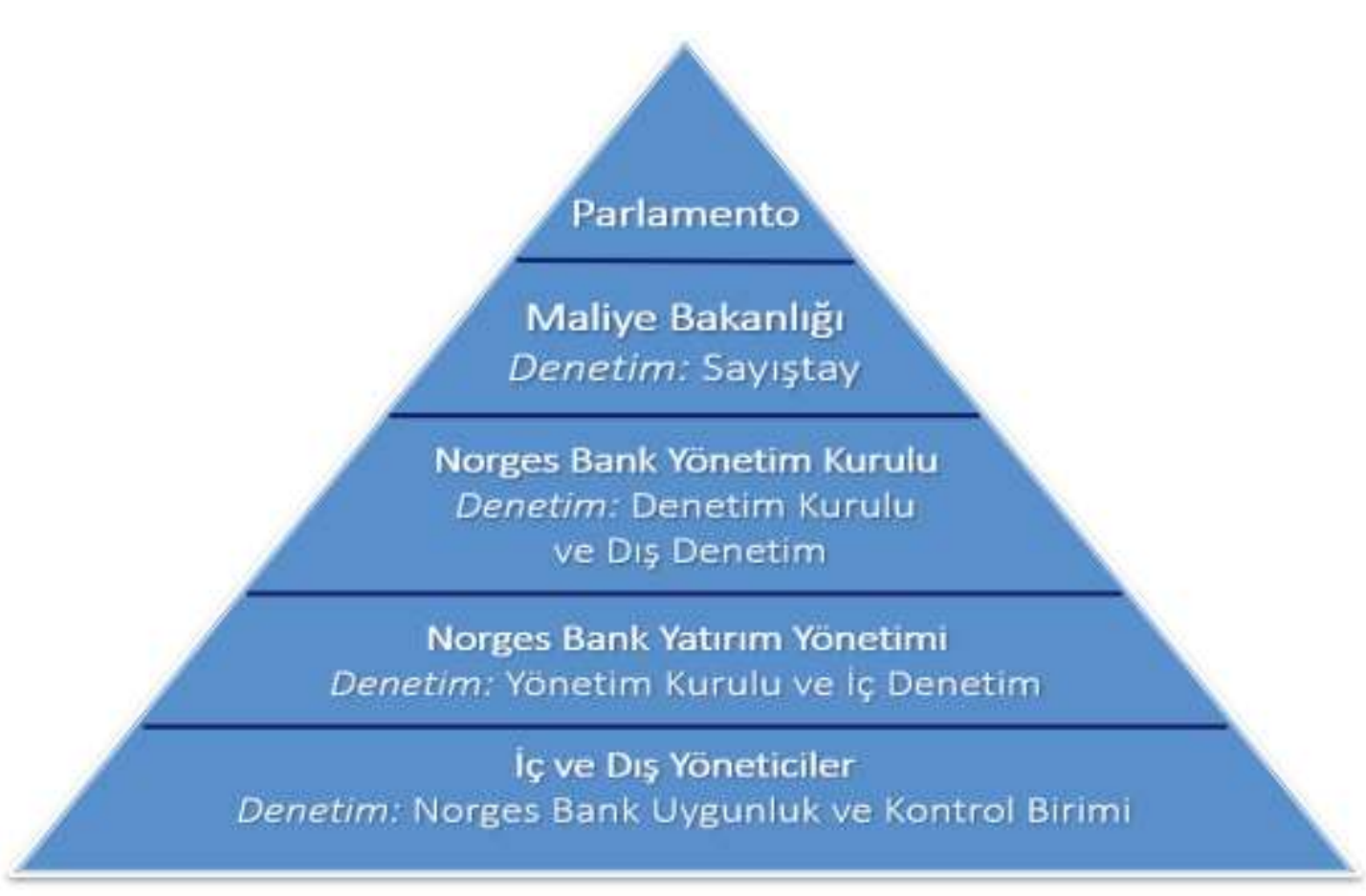

Kaynak: Norwegian Ministry of Finance, Governance Framework, https://www.regjeringen.no/en/ topics/the-economy/the-government-pension-fund/government-pension-fund-global-gpfg/governanceframework-for-the-government-/id696848/, (Erişim Tarihi: 18.05.2020)

Fonun bağlı bulunduğu Maliye Bakanlığı ise her yıl bahar oturumunda Parlamentoya fonun yönetimi hakkında yılık bir rapor (White paper) sunmaktadır. Söz konusu raporlar kamuya açıktır. Raporun ekinde Norges Bank'ın o yıl sunduğu yıllık rapor da bulunmaktadır. Maliye Bakanlığının sunduğu yıllık raporlarda fonun sermayesinin yönetimi ile ilgili genel konular yer almaktadır. Petrol gelirlerinin yönetimi, fonun ekonomi içindeki durumu ve petrol gelirlerinin ne kadarının harcanacağı gibi daha genel konular ise mali yıl bütçesi ile birlikte sonbahar oturumunda tartışılmaktadır (Norwegian Ministry of Finance, 2006: 7).

Maliye Bakanlığının denetiminden Sayıştay (the Office of the Auditor General of Norway) sorumludur, söz konusu kurum Bakanlığın Fon ile ilgili işlemlerinin Parlamentonun kararlarına uygun olmasını sağlar (Norwegian Ministry of Finance, 2017: 9) ve doğrudan Parlamentoya rapor verir (Backer, 2009: 139).

Birçok diğer ulusal varlık fonu gibi GPFG, uluslararası alanda da denetlenmektedir. Ancak söz konusu denetimler zorunlu denetimler olmayıp ihtiyaridir. Ulusal varlık fonları bu denetimlere katılarak, amaçlarının sadece ekonomik olduğunu ve politik amaçlarının olmadığını kanıtlamaya çalışırlar. Söz konusu denetlemeler şeffaflık derecelendirmeleri ile yapılmaktadır. Bunlar; Truman 
Derecelendirmesi, Linaburg-Maduell Derecelendirmesi ve Geoeconomica Derecelendirmesi olmak üzere üç tanedir (Durdu, 2018: 149-151).

Truman Derecelendirmesi, Edwin M. Truman tarafından 2007, 2009, 2012 ve 2015 yılları için yapılmıştır. GPFG bu derecelendirmelerde 2007 yılında 37 ülke arasından, 2009 yılında 44 ülke arasından, 2012 yılında 49 ülke arasından 97 puanla, 2015 yılında ise 60 ülke arasından 98 puanla birinci seçilmiştir (Peterson Institute for International Economics, 2016).

Linaburg-Maduell Derecelendirmesi ise 2008 'de Carl Linaburg ve Michael Maduell tarafından Şeffaflık Endeksi adı altında Ulusal Varlık Fonu Enstitüsünde geliştirilmiştir $^{11}$. Sürekli güncellenen bu endeks 2020 yılında 49 ulusal varlık fonunu derecelendirmiştir. Söz konusu fonlar arasında 15 ulusal varlık fonu 10 tam puan almıştır. Bu fonlardan biri de GPFG'dir (SWFI Institute, 2020b).

Geoeconomica Derecelendirmesi ise Santiago ilkelerine ${ }^{12}$ uyumu ölçmektedir. 2014 yılında yayımlanan son güncellemede GPFG, A- derecelendirmesi ile söz konusu ilkelere tamamen uyumlu olarak görülmektedir (Geoeconomica, 2014: 2). Ayrıca Fon yönetimi de belirli aralıklarla Fonun Santiago Prensiplerine uyumu ile ilgili raporlar yayınlamaktadır.

\subsubsection{Etik Konseyi}

GPFG resmi olarak Maliye Bakanlığına bağlı olmasının yanında aynı zamanda Norveç vatandaşlarının da mülküdür. Bu nedenle kamuoyundan da oldukça etkilenebilmektedir. 1998 yılında öz sermaye yatırımları yapmaya başladığı zaman, vatandaşlar tarafından fonun yalnızca nesiller arası adalet tahsisinin sağlanması için kullanılmaması gerektiği, aynı zamanda Fonun evrensel olarak kabul edilmiş değer ve normların uygulanmasına da katkıda bulunması gerektiği görüşü dile getirilmiştir. Çünkü o yıllarda Norveçli bir sigorta şirketi tarafından hazırlanan raporla, Fonun etik dışı faaliyetleri olan birçok şirkete yatırım yaptığı ortaya çıkarılmıştır (Wirth, 2018: 186).

Bunun üzerine Maliye Bakanlığı tarafından 2002 yılında bir komisyon kurulmuştur. Komisyonun 2003 yılında yayınladığı raporda; BM ve OECD ilkelerine dayanan, insan hakları, yönetişim ve çevre gibi konularla ilgili olmak üzere, uluslararası kabul görmüş etik değerler tanımlanmıştır. Raporda iki ana etik değerin var olması gerektiği özellikle vurgulanmıştır. Söz konusu etik değerlerden birincisi petrol gelirlerinin az olduğu dönemler de dâhil olmak üzere Fona transfer gerçekleştirilerek petrolden elde edilen servetin kuşaklararası dağıtılmasının sağlanmasıdır. İkinci etik

\footnotetext{
${ }^{11}$ Değerlendirme 10 puan üzerinden yapılmaktadır.

${ }^{12}$ Bu ilkeler varlık fonlarının yasal çerçevesi, hedefleri, yönetim yapısı, yatırım ve risk yönetim çerçevesi gibi bileşenlerinin nasıl olması gerektiği ile ilgili 2008 yılında Santiago'da kabul edilen 24 ilke ve uygulamayı içermektedir (Özgül, 2018: 65-67).
} 
değer ise yatırım yapılacak firmaların temel özgürlük ve haklara saygılı olması gerekliliğidir. 2004 yılının sonunda Parlamento, GPFG için hazırlanan söz konusu Etik Kuralları (Ethical Guidelines for the GPFG) kabul etmiştir (Wirth, 2018: 186-187).

Bu toplantıda aynı zamanda Etik Konseyi (The Council on Ethics) kurulmuştur. $\mathrm{Bu}$ konsey, Maliye Bakanlığı ve Norges Bank'a ${ }^{13}$ tavsiyelerde bulunmakla görevli bağımsız bir konseydir. Konseyin görevi; fonun yatırım yapacağı şirketlerin kabul edilen Etik Kurallardaki kriterlere uyup uymadığını incelemektir. Konsey bugüne kadar etik değerleri ihlal eden birçok şirket için Norges Bank'a önerilerde bulunmuştur. Norges Bank da çoğunlukla bu önerileri takip etmiştir, ancak önerilere uyma zorunluluğu yoktur (Council on Ethics Government Pension Fund - Global, 2005: 5; 2017: 7) ${ }^{14}$.

\section{3. İ̧̧leyiş Mekanizması}

Norveç Varlık Fonu aslında Maliye Bakanlığı tarafından Norges Bank'a yatırılan Norveç Kronu cinsinden bir mevduat hesabıdır. Banka, Bakanlıktan aldığı yetkiyle bu mevduatı çeşitli finansal araçlara yatırım yapmak için kullanır. Söz konusu hesabın yani fonun değeri, yatırım portföyünün net muhasebe değerine eşittir. Yatırım portföyünden gelen getirilerden Banka'nın yönetim maliyetleri düşüldükten sonra bu getiriler mevduat hesabına eklenir. Bankanın amacı yatırımlardan mümkün olan en yüksek getiriyi elde etmektir (Norwegian Ministry of Finance, 2019a: 1-2).

Fonun işleyiş mekanizmasının anlaşılabilmesi için petrol gelirleri, bütçe ve Fon arasındaki ilişkiyi anlamak gerekir. Norveç, petrol sektöründen önemli gelirler elde etmektedir.

Şekil 5'den de görülebileceği gibi söz konusu gelirlerin bir kısmı petrol dışı bütçe açığını ${ }^{15}$ finanse etmek için hazineye transfer edilir. Kalan kısım ise Fon'a aktarılır (Aamodt, 2012: 1). Fonun sermayesi ise yalnızca Norveç Parlamentosu'nun kararıyla merkezi yönetim bütçesine yapılan transferlerde kullanılabilir. Hükümet Fon'da sermaye bulunduğu sürece harcamalarını borçlanarak finanse edemez. Ancak likidite ihtiyacı olduğu durumlarda Fonun sermayesi kullanılamıyorsa geçici olarak borçlanılabilir (Government Pension Fund Act, 2020).

\footnotetext{
13 Yatırım tavsiyeleri 2015 yılına kadar Maliye Bakanlığına iletilmiş, 2015 yılı itibariyle ise doğrudan Norges Bank'a iletilmeye başlanmıştır.

${ }^{14}$ Konsey yatırım yapılacak şirketlerde; Cinayet, işkence, zorla çalıştırma, çocuk işçiliği ve çocuk sömürü biçimlerinin her türlü halleri gibi insan hakları ihlalleri, şiddetli çevresel zararlar, silah üretimleri, sera gazı emisyonları, yolsuzluk ve temel etik normların ciddi ihlalleri gibi birçok durumun mevcudiyetine dikkat etmektedir (Council on Ethics Government Pension Fund - Global, 2005: 6).

${ }^{15}$ Bütçe gelirlerinden petrol gelirleri çıkarıldığı zaman oluşan açıktır. Şu şekilde formüle edilebilir; [(Bütçe Gelirleri-Petrol Gelirleri) - Bütçe Harcamaları)].
} 


\subsubsection{Mali Kural}

2001 yılında yetkililer, fonun yılsonundaki değerinin yalnızca \%4'ünün bütçe açığını finanse etmek için transfer edilebilmesi ile ilgili düzenleme yapmışlardır. Mali kural olarak da adlandırılan \%4'lük oranın belirlenmesinde fonun yatırımlarından beklediği reel getiri oranı dikkate alınmış (Wirth, 2018: 184) ve söz konusu oran 2017 yılında \%3 olarak yeniden düzenlenmiştir. Bu sayede fondan merkezi yönetim bütçesine yapılacak transferlerin zaman içinde fonun beklenen reel getirisine eşitleneceği ifade edilmekte (Norwegian Ministry of Finance, 2019c) ve bu getirinin kalıcı bir gelir olarak zamanla petrol dışı bütçe açı̆̆ını finanse edebileceği vurgulanmaktadır. Böylece sürekliliği olmayan petrol gelirleriyle finanse edilen bütçenin, ekonomik dalgalanmalardan etkilenmesinin de önlenmiş olacağı varsayılmaktadır (Norwegian Ministry of Finance, 2006: 8) ${ }^{16}$.

Bir diğer ifadeyle petrol dışı bütçe açığını kapatmak için Fonun sermayesi değil, zamanla sadece yatırımlardan beklenen reel getiri ${ }^{17}$ kullanılacaktır. Bu süreç aynı zamanda petrol gelirlerinin bütçe dışına aktarılarak nasıl kullanıldığının izlenmesini de mümkün kılar. Böylece bütçenin petrol dışı dengesi de görülebilir. Cari yılın petrol dışı bütçe açığının büyüklüğü Fon'a yapılan net transfer miktarını da belirler (Şekil 5).

\footnotetext{
${ }^{16}$ Norveç Varlık Fonu yasasına göre Fonun gelirleri; merkezi yönetim bütçesinden transfer edilen petrol faaliyetlerinden elde edilen net nakit akışından, petrol faaliyetleriyle ilişkili net finansal işlemlerin sonuçlarından ve fonun yatırım getirilerinden oluşmaktadır.

1. Petrol faaliyetlerinden elde edilen net nakit akışı brüt gelirlerden petrol için yapılan harcamalar düşülerek elde edilir.

Söz konusu brüt gelirler;

$>$ Petrol faaliyetleri ile ilgili toplanan vergiler,

$>$ Karbondioksit (CO2) emisyonundan alınan vergiler,

$>$ Azot oksit (NOx) emisyonundan alınan vergiler,

$>$ Petrol faaliyetleri ile ilgili SDFI'den gelen işletme gelirleri ve diğer gelirler,

$>$ Üretim lisansları ile ilgili yapılan kar anlaşmalarından elde edilen gelirler,

$>$ Equinor ASA'dan gelen kar payları,

$>$ Kıta sahanlı̆ındaki tesislerin kaldırılması veya alternatif kullanımı ile ilgili gelirler,

$>$ Petrol faaliyetleri ile ilgili SDFI'yi temsil eden hisse senedi satışından elde edilen gelirlerdir.

Söz konusu harcamalar;

> Petrol faaliyetleri dolayısıyla SDFI'ye yapılan yatırımlar,

$>$ Petrol faaliyetleri dolayısıyla SDFI'nin işletme masrafları ve diğer harcamaları,

$>$ Kıta sahanlığındaki tesislerin kaldırılması veya alternatif kullanımı ile ilgili devletin yaptığı harcamalar,

$>$ SDFI'yi temsil eden hisse senedi alımlarıdır.
}

2. Petrol faaliyetleri ile ilgili net finansal işlemler, merkezi yönetimin Equinor ASA'daki hisselerinin satışlarından elde edilen toplam brüt gelirlerinden hisse senedi alımları ve sermaye payının olduğu şirketlerdeki sermaye katkısının çıkarılmasıyla elde edilmektedir (Government Pension Fund Act, 2020).

${ }^{17}$ Brüt getiriden, enflasyon ve yönetim maliyetleri çıkarıldıktan sonra elde edilen getiridir. 
Şekil 5. Fon Mekanizması
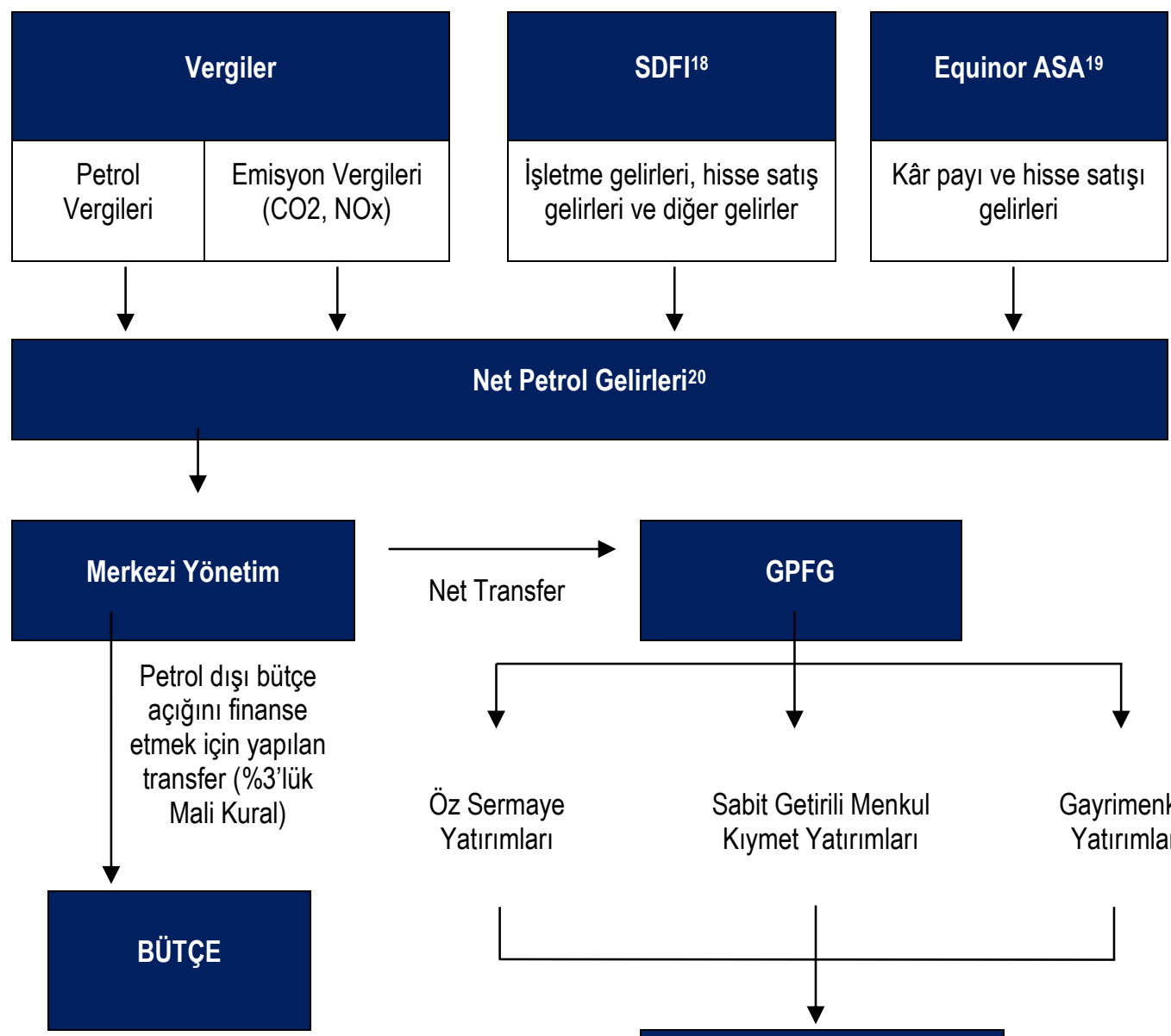

Net Petrol Gelirleri20

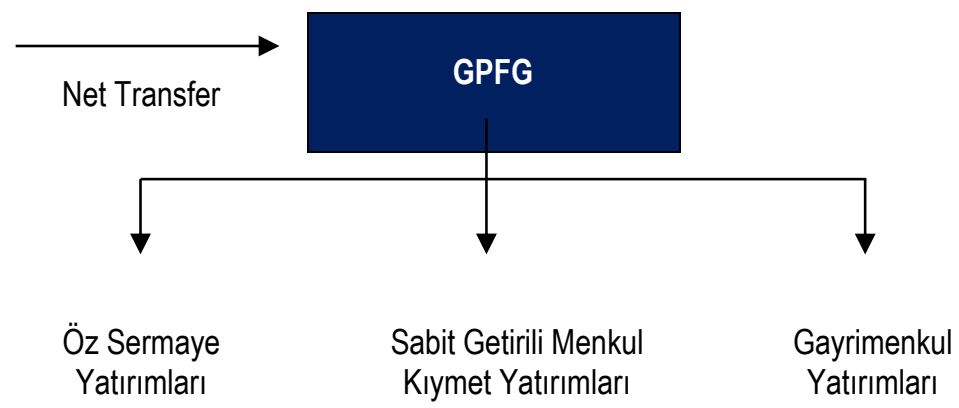

Kaynak: Wirth, E. \& Ramirez- Cendrero, J. M. (2016). Fiscal Policy And Sovereign Wealth Funds In OilRich Economies: The Norwegian Case, XVIII Reunión de Economía Mundial Conference, p.8'den yararlanılarak yazar tarafından geliştirilmiştir.

Petrol ve gaz fiyatlarında veya petrol üretimindeki değişiklikler petrol gelirlerini, işsizlik ödemeleri ve vergi gelirlerindeki değişimler ise petrol dışı bütçe açığını etkiler. Ekonominin iyi performans gösterdiği dönemlerde petrol dışı bütçe açığı azalır ve fona

\footnotetext{
${ }^{18}$ Açılımı State's Direct Financial Interest olan portföy 1985 yılında kurulmuştur. Norveç'in petrol ve gaz rezervlerinin yaklaşık $1 / 3^{\prime}$ ü için lisans sahibidir. Amacı devlet için maksimum gelir sağlamaktır (Petoro, 2020).

191972 yılında Statoil (Devlet Petrol Şirketi) adıyla kurulan şirket 2018'de Equinor ASA olarak yeniden adlandırılmıştır. Norveç Devleti şirketin hisselerinin \%67'sine sahiptir (Equinor, 2020).

${ }^{20}$ Vergiler ile SDFI ve Equinor ASA'dan elde edilen gelirlerden petrol faaliyetleri için yapılan harcamaların çıkarılmasıyla elde edilmektedir.
} 
yapılan net transferler artış gösterirken, ekonominin kötü olduğu yıllarda petrol dışı bütçe açığı artar ve fona yapılan net transferler azalır (Aamodt, 2012: 3).

$>$ Bütçeye yapılan transfer= Petrol dışı bütçe açığı

$>$ Petrol gelirleri- Bütçeye yapılan transfer= Fona yapılan net transfer

$>$ Petrol gelirleri- Petrol dışı bütçe açığı= Fona yapılan net transfer

\subsection{Yatırım Stratejisi}

Daha öncede belirtildiği gibi Norveç Varlık Fonu 1990'daki kuruluşunun ardından ilk sermaye transferini 1996 yılında almıştır. Ardından yalnızca 8 ülkeyi kapsayan, devlet tahvillerini ve devlet garantili menkul kıymetleri içeren sabit getirili menkul kıymet yatırımları (Fixed Income) yapmaya başlamıştır (Norwegian Ministry of Finance, 2014: 15).

Fon 1997 yılında öz sermaye yatırımları yapmak için hazırlanmaya başlamış ve bu yatırımları yönetmesi için 1998'in ilk aylarında Norges Bank Yatırım Yönetimi (NBIM) adlı yeni bir departman kurmuş ve fonun o sırada 14 milyar Euro olan varlıklarının yönetimini bu departmana devretmiştir (Skancke, 2003: 330). Fon bunun sonucunda \%40'ık başlangıç payı ile öz sermaye yatırımları (Equities) yapmaya başlamıştır. Bu atılımın arkasındaki düşünce, hisse senetlerinin zaman içinde devlet tahvillerinden daha fazla getiri elde edeceği olmuştur. Bu sayede birden fazla varlık sınıfına yatırım yapmanın riskin dağıtılmasında yardımcı olacağı da öngörülmüştür (Norwegian Ministry of Finance, 2014: 15).

2000 yılında bazı gelişmekte olan piyasalarda hisse senedi yatırımlarına dâhil edilmiş ve fon yatırımları 21 ülkeyi kapsayacak şekilde genişletilmiştir. 2002 yılında devlet garantili olmayan menkul kıymetlerde sabit getirili menkul kıymet yatırımlarına dâhil edilmiştir. 2007 yılında öz sermaye yatırımlarının oranı \%40'dan \%60'a çıkarılmıştır (günümüzde \%70). 2008 yılında öz sermaye yatırımlarının kapsamı bütün gelişmekte olan piyasaların ${ }^{21}$ dâhil edilmesi ile daha da genişletilmiştir (Norwegian Ministry of Finance, 2014: 17).

Ayrıca yine 2008 yılında fonun en fazla \%5 (günümüzde \%7) olacak şekilde gayrimenkul yatırımları (Real Estate) yapmasına izin verilmiştir. ilk gayrimenkul yatırımları büyük Avrupa şehirlerine yapılmıştır. 2013 yılından sonra daha küresel çapta gayrimenkul yatırımları yapılabilmesi için GPFG'nin yatırım stratejisi değiştirilmiştir (Norwegian Ministry of Finance, 2014: 18).

\footnotetext{
${ }^{21}$ Bu piyasalar; FTSE Grup tarafından İleri Düzey Gelişmiş (Advanced Emerging) ve İkincil Gelişmiş Piyasalar (Secondary Emerging) olarak tanımlanan bütün piyasalardır. Detaylı bilgi için bknz: https://www.ftse.com/products/indices/country-classification (26.02.2019).
} 
Şekil 6. GPFG'nin Yatırım Dağılımı (2019 Sonu) (\%)

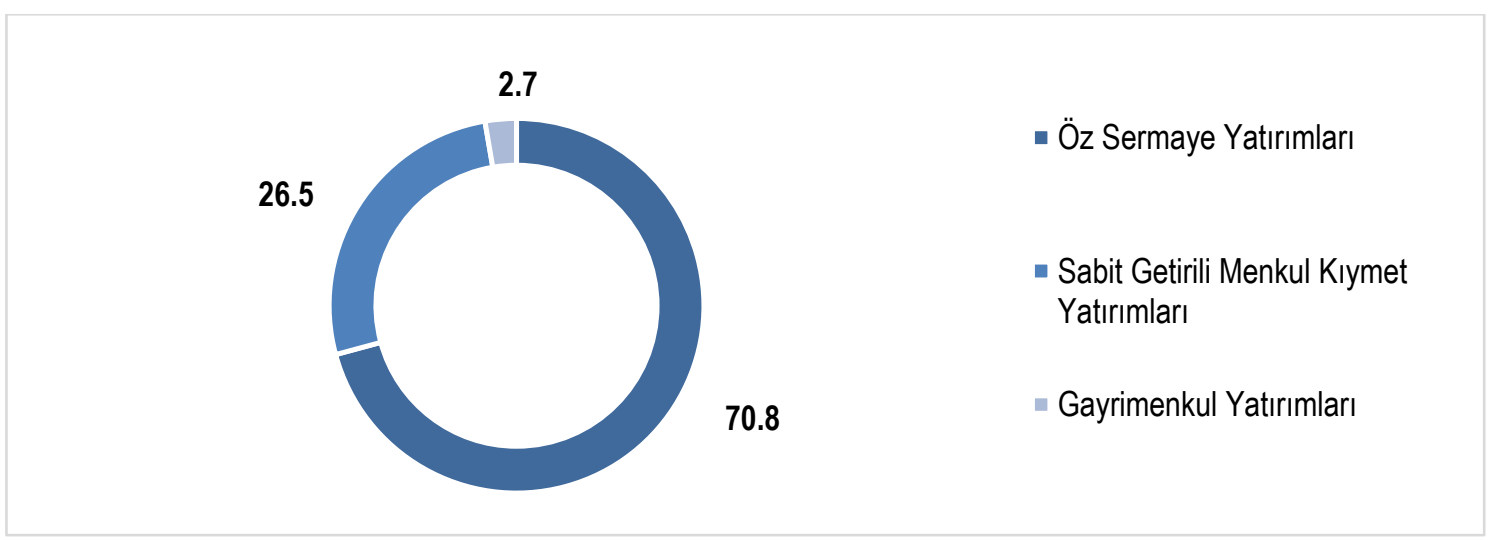

Kaynak: Norges Bank, 2019: 5.

Fon günümüzde 74 ülkede 9200'den daha fazla şirkete yatırım yapmaktadır (Norges Bank, 2019: 30). Şekil 6'dan da görülebildiği gibi GPFG'nin yatırım dağılımında en büyük payı \%70.8 ile öz sermaye yatırımları oluşturmaktadır. Öz sermaye yatırımları içerisinde ise en fazla finans, teknoloji ve endüstri sektörlerine yatırım yapıldığı görülmektedir (Şekil 7).

Şekil 7. Öz Sermaye Yatırımlarının Sektörel Dağılımı (2019 Sonu) (\%)

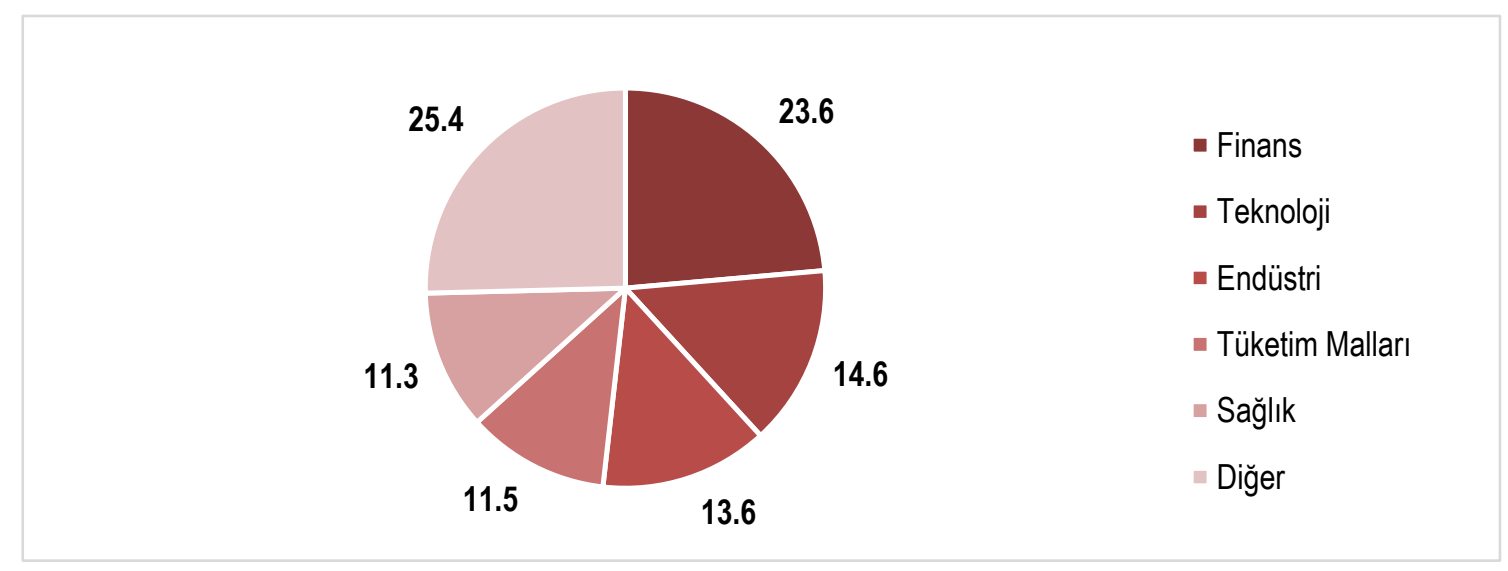

Kaynak: Norges Bank, 2019: 45.

Tablo 2'den de görülebileceği gibi GPFG'nin yatırımlarının bölgesel dağılımında en yüksek pay Kuzey Amerika bölgesindedir. Bunu \%33.5 ile Avrupa izlemektedir. Dağılıma ülke açısından bakıldığında toplam yatırımların \%39.8'inin Amerika Birleşik Devletleri'ne, \%8.8'inin Birleşik Krallık'a, \%8.5'inin ise Japonya'ya yapıldığı görülmektedir. 
Özgül, H. B. (2020). “Norveç Varlık Fonu Üzerine Bir İnceleme”, International Journal of Public Finance, 5(1), 101-126.

Tablo 2. Öz Sermaye Yatırımlarının Bölgesel Dağılımı (2019 Sonu) (\%)

\begin{tabular}{|l|r|c|l|}
\hline Bölge/Ülke & Piyasa Değeri (\$) & $(\%)$ & Sektör* \\
\hline Kuzey Amerika & $\mathbf{3 4 1 . 2 0 1 . 0 7 7 . 4 9 3}$ & $\mathbf{4 2}$ & Finans \\
\hline ABD & 323.394 .993 .669 & 39.8 & Teknoloji \\
\hline Kanada & 17.806 .083 .824 & 2.2 & Finans \\
\hline Avrupa & $\mathbf{2 7 2 . 0 3 2 . 6 5 1 . 7 6 1}$ & $\mathbf{3 3 . 5}$ & Finans \\
\hline Birleşik Krallık & 71.295 .634 .824 & 8.8 & Finans \\
\hline Fransa & 41.939 .687 .755 & 5.2 & Tüketim Malları \\
\hline Almanya & 39.072 .729 .182 & 4.8 & Finans \\
\hline İsviçre & 37.893 .994 .355 & 4.7 & Sağlık \\
\hline Türkiye & 803.078 .354 & 0.1 & Finans \\
\hline Diğer & 81.027 .527 .291 & 9.9 & - \\
\hline Asya & 162.714 .488 .689 & $\mathbf{2 0}$ & Finans \\
\hline Japonya & 68.860 .225 .704 & 8.5 & Sanayi \\
\hline Çin Halk Cumhuriyeti & 35.134 .558 .655 & 4.3 & Tüketim Hizmetleri \\
\hline Diğer & 58.719 .704 .330 & 7.2 & - \\
\hline Diğer & $\mathbf{3 8 . 0 6 1 . 8 7 3 . 4 3 1}$ & $\mathbf{4 . 5}$ & Finans \\
\hline
\end{tabular}

Kaynak: Norges Bank, https://www.nbim.no/en/the-fund/holdings/holdings-as-at-31.12.2019/? fullsize=true (Erişim Tarihi: 25.05.2020).

*Ülke ve bölgelerde ağırlıklı olarak yatırım yapılan sektör.

GPFG'nin 2020 yılı itibariyle Türkiye'ye 803 milyon dolar öz sermaye, 497 milyon dolar sabit getirili menkul kıymet olmak üzere toplamda 1.3 milyar dolar (Fonun toplam yatırımları içinde $\% 0.1$ ) yatırımı bulunmaktadır.

\section{Şekil 8. GPFG'nin Türkiye Yatırımlarının Gelişimi (2001-2019) (\$)}

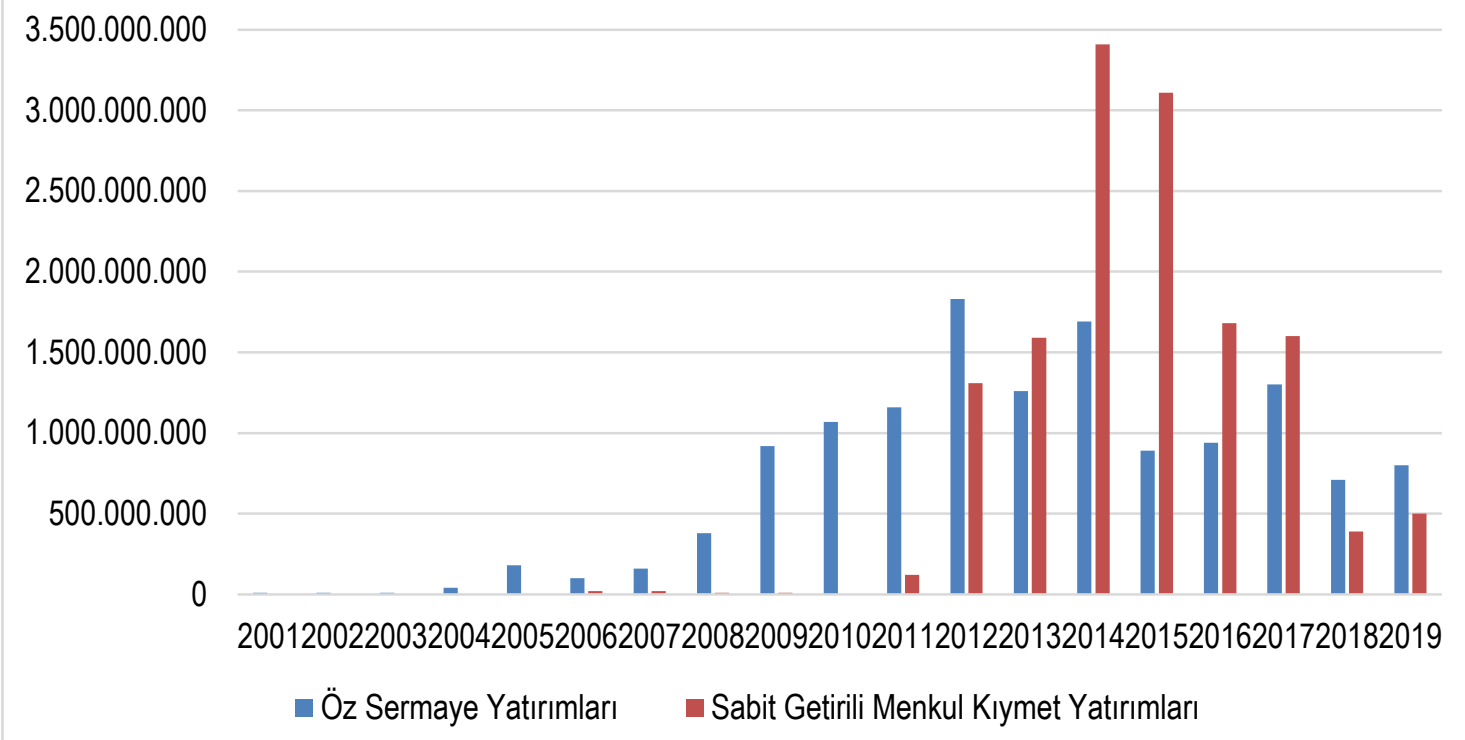

Kaynak: Norges Bank, https://www.nbim.no/en/the-fund/holdings/holdings-as-at-31.12.2019 /?fullsize=true (Erişim Tarihi: 19.05.2020). 
Tablo 3. GPFG'nin Türkiye'deki En Büyük 5 Öz Sermaye Yatırımı (2019 Sonu)

\begin{tabular}{|l|l|c|c|}
\hline Firma & Sektör & Piyasa Değeri (\$) & $\mathbf{( \% )}^{\mathbf{*}}$ \\
\hline Akbank T. A.Ş. & Finans & 101.651 .998 & 12.7 \\
\hline Türkiye Garanti Bankası A.Ş. & Finans & 70.152 .015 & 8.7 \\
\hline Türk Hava Yolları A.O. & Tüketim Hizmetleri & 54.741 .609 & 6.8 \\
\hline Tüpraş Türkiye Petrol Rafinerileri A.Ş. & Petrol ve Gaz & 54.653 .335 & 6.8 \\
\hline Arçelik A.Ş. & Tüketim Malları & 47.651 .306 & 5.9 \\
\hline
\end{tabular}

Kaynak: Norges Bank, https://www.nbim.no/en/the-fund/holdings/holdings-as-at-31.12.2019 /?fullsize=true (Erişim Tarihi: 19.05.2020).

*Türkiye'ye yapılan öz sermaye yatırımlarının toplamı içindeki pay.

Şekil 8'den de görülebileceği üzere GPFG Türkiye'ye 2001 yılından itibaren öz sermaye yatırımları yapmaya başlamış, söz konusu yatırımlar 2012 yılında 1.8 milyar dolarla en yüksek seviyeye ulaşmıştır. Günümüz itibariyle ise Türkiye'de 53 şirkete 800 milyon dolar öz sermaye yatırımı yapılmaktadır.

GPFG'nin sabit getirili menkul kıymet yatırımları öz sermaye yatırımlarına nazaran daha yenidir. 2006 yılında 20 milyon dolar ile başlayan tahvil ve bono alımları 2014 yılında 3.4 milyar doları aşarak en yüksek seviyesine ulaşmıştır. Günümüzde devlet tahvilleri ve Türkiye Vakıflar Bankasına yaklaşık 500 milyon dolar yatırım yapılmaktadır.

\section{Grafik 3. GPFG'nin Türkiye Öz Sermaye Yatırımlarının Sektörel Dağııımı (\%)}

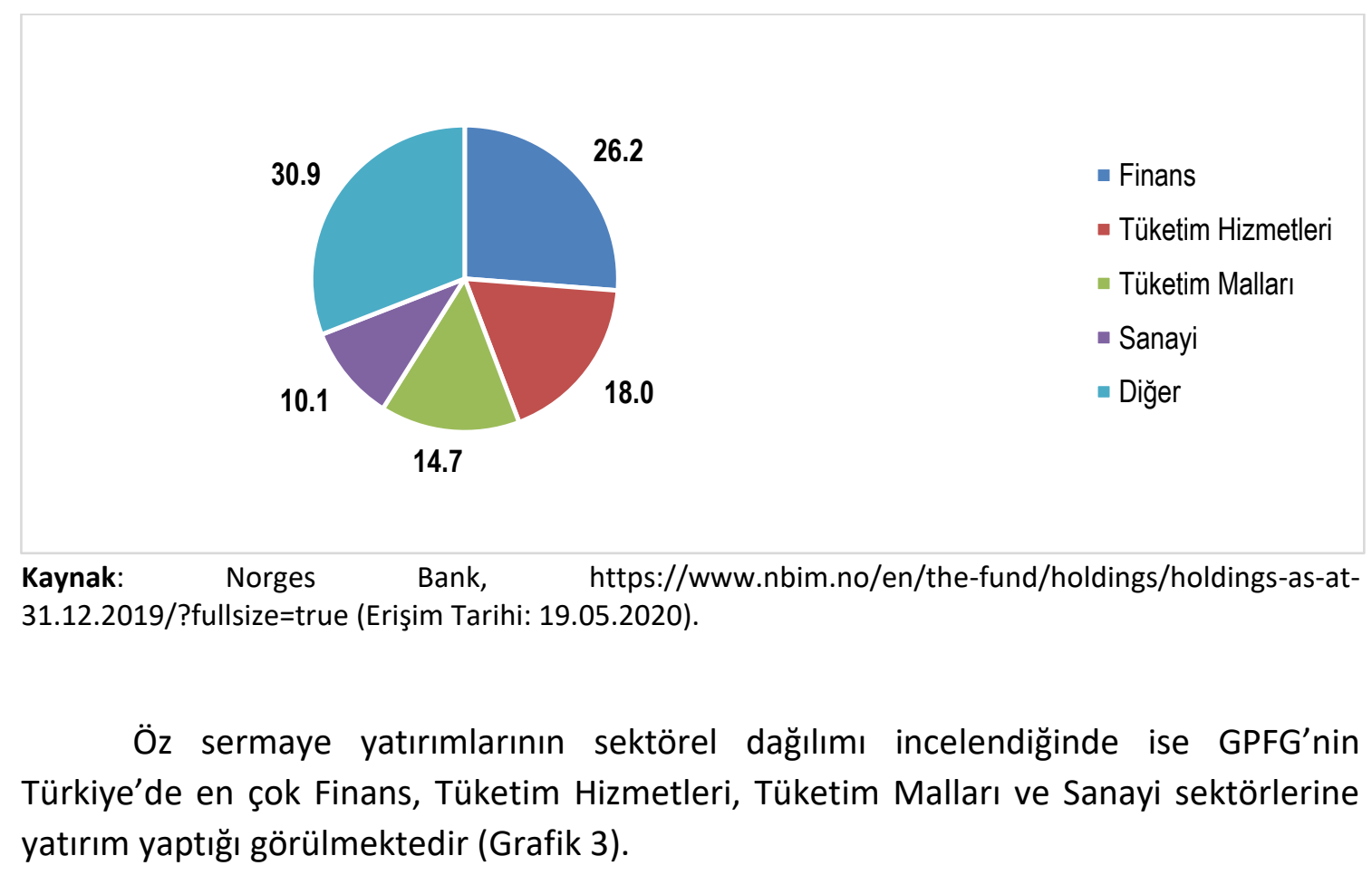




\section{Sonuç ve Değerlendirme}

Günümüzde sayıları 91'e ulaşan ulusal varlık fonlarının toplam değeri 8.189 trilyon dolara yükselmiştir. Bu değerin \%14.5'ini ise tek başına Norveç Varlık Fonu oluşturmaktadır. Çalışmada dünyanın en büyük varlık değerine sahip ulusal varlık fonu olması dolayısıyla Norveç Varlık Fonu incelenmiştir.

Norveç'in kıta sahanlığında petrol bulunup işlenmesinin ardından zamanla biriken gelirlerin, yapılan projeksiyonlar vasıtasıyla yaşlanan nüfusun gelecekteki emeklilik harcamalarına yetmeyeceği öngörülmüştür. Bu sebepten gelirin daha uzun vadeli kullanılması ihtiyacı doğmuş ve bu ihtiyacın sonucunda ise ulusal bir varlık fonu kurulmuştur. Kuruluşunda, Fonun bağı olduğu Maliye Bakanlığı ile operasyonel yönetimini yürüten Merkez Bankasının aralarında bir yönetim anlaşmasının imzalanması, görev ve sorumlulukların net bir şekilde belirlenerek fonun iyi yönetilmesini sağlamıştır. Ayrıca Fonun yatırımlarını Kuzey Amerika, Avrupa ve Asya gibi birçok bölgede Finans, Teknoloji ve Endüstri gibi birçok sektöre yönlendirmesi ekonomik dalgalanmalarda oluşabilecek riski de en aza indirerek varlıkların dağıtılması açısından iyi bir strateji olmuştur.

Fonun kuruluş kanununda Fon gelirlerinin sadece merkezi yönetim bütçe açığının finansmanında kullanılabileceği belirtilmiştir. Kuruluşundan 11 yıl sonra ise merkezi yönetim bütçesine yapılan aktarımların bir sınırı olması gerektiğine karar verilmiş ve Fon değerinin yalnızca \%4'ünün (2017 itibariyle \%3) petrol dışı bütçe açığını kapatmak için kullanılabilmesiyle ilgili bir mali kural uygulamaya koyulmuştur. Söz konusu oran ayrıca Fonun yatırımlarından beklenen reel getiriyi de ifade etmektedir. Bir diğer ifadeyle yöneticiler, petrol dışı bütçe açığının uzun dönemde Fonun sermayesinden ziyade Fonun yatırımlarından beklenen reel getiriyle finanse edilmesini hedeflemişlerdir. Bu vasıtayla bir gün petrol gelirleri tükense dahi beklenen reel getiriler, bütçe açığını finanse etmeye devam edebilecektir.

Fonun kurulduğu ilk günden itibaren şeffaflık ve hesap verilebilirliği ön planda tutması Fonun örnek gösterilen bir hale gelmesinde önemli bir rol oynamaktadır. Özellikle Etik Konseyi ile yatırım yapılan şirketlerin çevresel ve etik değerlere yaklaşımının değerlendirilmesi gelecek nesiller için ekonomik refahın yanında daha iyi bir çevre bırakılmasının da hedeflendiğini göstermektedir.

Norveç örneğinde görüldüğü gibi ulusal bir varlık fonunun başarılı olabilmesi için iyi yönetim, şeffaflık ve hesap verilebilirlik önemli faktörlerdir. 1996 yılında ilk sermaye tahsisini alan Norveç Varlık Fonu, söz konusu faktörler sayesinde günümüzde 74 ülkede 9200 'den fazla şirkete yatırım yapan ve dünyanın en büyük ulusal varlık fonu olma özelliğini gösteren bir varlık fonu haline gelmiştir. Buna bağlı olarak 2016 yılında ülkemizde kurulan ve yeni bir ulusal varlık fonu olarak kabul edilen Türkiye Varlık Fonu'nun da dünyada tanınan bir fon olabilmesi için mali işlemlerini yönetecek kurumlar arasında koordinasyon sağlaması ve bunun yanında fon yönetiminde şeffaflık ve hesap verebilirlik geleneğini mutlaka kurması gerekmektedir. 


\section{Kaynakça}

Aamodt, E. (2012). The Petroleum Fund Mechanism and Norges Bank's Foreign Exchange Purchases for the GPFG, Norges Bank Economic Commentaries, No:14.

Aizenman, J. \& Glick, R. (2009). "Sovereign Wealth Funds: Stylized Facts about their Determinants and Governance", International Finance, 12(3), 351-386.

Akbulak, S. \& Akbulak, Y. (2008). "Ulusal Varlık Fonları", Marmara Üniversitesi i.i.B.F Dergisi, 15(2), 237-262.

Akyol, M. \& Hayaloğlu, P. (2017). "Kurumsal Yapının Ülkelerin Varlık Fonları Üzerindeki Etkisi: Dinamik Panel Veri Analizi", International Journal of Disciplines Economics \& Administrative Sciences Studies, 3(4), 270-279.

Alhashel, B. (2015). "Sovereign Wealth Funds: A Literature Review", Journal of Economics and Business, 78, 1-13.

Al-Hassan, A., Papaioannou, M.G., Skancke, M. ve Sung, C. C. (2013). Sovereign Wealth Funds: Aspects of Governance Structures and Investment Management, IMF Working Paper.

Aykın, H. (2011). Ulusal Refah Fonları: Risk mi, Fırsat mı?, Stratejik Düşünce Enstitüsü Yayınları.

Backer, L.C. (2009). "Sovereign Wealth Funds as Regulatory Chameleons: The Norwegian Sovereign Wealth Funds and Public Global Governance Through Private Global Investment", Georgetown Journal of International Law, 41(2), 101-192.

Balding, C. (2011). "A Portfolio Analysis of Sovereign Wealth Funds", Sovereign Wealth: The Role of State Capital in the New Financial Order, (Ed.) Fry, R., McKibbin, W.J., O’Brien, J., Imperial College Press, 43-70.

Balin, B. J. (2009). Sovereign Wealth Funds: A Critical Analysis, https://ssrn.com/abstract= 1477725, (26.06.2020).

Bayar, Y. \& Yıldırım, M. (2013). "Ulusal Varlık Fonlarının Regülasyonuna Yönelik Çabalar: Santiago Prensipleri", Finans Politik \& Ekonomik Yorumlar Dergisi, 50(585), 67-79.

Beck, R. \& Fidora, M. (2008). "The Impact of Sovereign Wealth Funds on Global Financial Markets", Intereconomics, 349-358.

Bernstein, S., Lerner, J. \& Schoar, A. (2013). "The Investment Strategies of Sovereign Wealth Funds", Journal of Economic Perspectives, 27(2), 219-238.

Clark, G. L., Dixon, A. D., \& Monk, A. H. B. (2013). Sovereign Wealth Funds: Legitimacy, Governance, and Global Power, Princeton University Press.

Clark, G. L., Monk, A. (2010). “The Norwegian Government Pension Fund: Ethics over Efficiency", Rotman International Journal of Pension Management, 3(1), 14-19.

Council on Ethics Government Pension Fund - Global. (2005). Annual Report 2005, https://etikkradet.no/annual-reports/\%22https://nettsteder.regjeringen.no/et ikkradet3/files/2017/02/rsmelding-2005-eng-1.pdf, (25.02.2019). 
Council on Ethics Government Pension Fund - Global. (2017). Annual Report 2017, https://nettsteder.regjeringen.no/etikkradet3/files/2018/03/Etikkradet_arsme Iding_2017_eng_UU.pdf, (25.02.2019).

Csoma, R. (2015). "Appreciation of the Role of Sovereign Wealth Funds in the Global Economy", Public Finance Quartely, 60(2), 270-287.

Dedekoca, E. (2012). "Devlet Yoluyla Kapitalizm”. 21. Yüzyılda Sosyal Bilimler Dergisi, 1, 73-89.

Demarolle, A. (2009). Report to The Government of France on Sovereign Wealth Funds, http://www.paris-europlace.net/files/rapport_demarolle_en.pdf, (20.05.2020).

Durdu, M. (2018). "Türkiye'de Bütçe Dışı Fon Uygulamaları ve Varlık Fonu", Yüksek Lisans Tezi, Selçuk Üniversitesi Sosyal Bilimler Enstitüsü, Konya.

Durdu, M. (2018). "Türkiye Varlık Fonu İçin Bir Uygulama Örneği: Singapur Temasek Holding", Necmettin Erbakan Üniversitesi Hukuk Fakültesi Dergisi, 1(2), 74-92.

Equinor. (2020). https://www.equinor.com/en/about-us.html (23.05.2020).

FTSE Group. (2019). https://www.ftserussell.com/equity-country-classification (26.02.2019).

Geoeconomica Political Risk Management. (2014). Santiago Compliance Index 2014, https://nzsuperfund.nz/assets/documents-sys/SCl-2014-October-2014_final.pdf, (19.05.2020).

Government Pension Fund Act. (2020). https://www.nbim.no/en/organisation /governance-model/government-pension-fund-act/, (22.05.2020).

Güçlü, M. (2018). "Ulusal Varlık Fonları: Türkiye Ekonomisi İçin Bir Değerlendirme”, Ege Stratejik Araştırmalar Dergisi, 9(1), 39-53.

Hacıhasanoğlu, E. \& Soytaş, U. (2010). Yeniden Tasarlanan Finansal Mimaride Ulusal Varlık Fonlarının Rolü, MARC Working Paper Series.

IFSWF. (2020). About Us, https://www.ifswf.org/about-us, (26.06.2020).

IWG. (2008). Sovereign Wealth Funds: Generally Accepted Principles and Practices "Santiago Principles", https://www.ifswf.org/sites/default/files/santia goprinciples_0_0.pdf, (25.02.2019).

Jen, S.L. (2009). “How Big Could Sovereign Wealth Funds Be By 2015?”, Revue d'Économie Financière, 195-198.

Johnson, S. (2007). The Rise of Sovereign Wealth Funds, Straight Talk, https://www.imf.org/external/pubs/ft/fandd/2007/09/pdf/straight.pdf, (26.06.2020).

Karagenç, G. K. (2017). "Varlık Fonunun İdare Hukuku Ille Kavran(Ama)ması", International Congress on Politic, Economic and Social Studies, 3.

Karagöl, E. T. \& Koç, Y. E. (2016). "Dünya'da Ve Türkiye'de Varlık Fonu”, Siyaset, Ekonomi ve Toplum Araştırmaları Vakfı Yayınları, 169, 7-25. 
Kayıran, M. (2016). “Türkiye Varlık Fonu'nun Kuruluş Amaçları ve Yapısı Üzerine Bir Değerlendirme", Eğitim Bilim Toplum Dergisi, 14(56), 55-90.

Keller, A. (2008). "Sovereign Wealth Funds: Trustworthy Investors or Vehicles of Strategic Ambition?", Georgetown Journal of Law \& Public Policy, 7(1), 333-372.

Konukman, A. \& Şimşek, O. (2017). "Ulusal Varlık Fonları ve Türkiye Uygulaması", Çalışma ve Toplum Dergisi, 4(55), 1913-1944.

Kunzel, P., Lu, Y., Petrova, I. K. \& Pihlman, J. (2011). Investment Objectives of Sovereign Wealth Funds- A Shifting Paradigm, IMF Working Paper, 11/19, https://ssrn.com/abstract=1755436, (26.06.2020).

Legislative Council Secretariat. (2014). Fact Sheet- Government Pension Fund of Norway, https://www.legco.gov.hk/research-publications/english/1314fsc50-governm ent-pension-fund-of-norway-20140902-e.pdf, (25.02.2019).

Nas, Ç. (2017). Varlık Fonları ve Uluslararası Kriterler. Iktisadi Kalkınma Vakfı Değerlendirme Notu.

Norges Bank. (1998). The Norwegian Government Petroleum Fund Annual Report, https://www.nbim.no/globalassets/reports/2000_1999_-1998/1998-en.pdf, (23.05.2020)

Norges Bank. (2008). Government Pension Fund - Global Annual Report, https://www.nbim.no/globalassetsreports/2008/2008-annual-report.pdf, (25.02.2019)

Norges Bank. (2019). Government Pension Fund - Global Annual Report, https://www.nbim.no/contentassets/3d447c795db84a18b54df8dd87d3b60e/spu_ annual_report_2019_en_web.pdf, (23.05.2020).

Norges Bank. (2020a). https://www.nbim.no, (18.05.2020).

Norges Bank. (2020b). https://www.nbim.no/en/the-fund/holdings/holdings-as-at31.12.2019/?fullsize=true, (19.05.2020).

Norwegian Ministry of Finance. (2006). On the Management of the Government Pension Fund in 2006, https://www.regjeringen.no/contentassets/eeb49ccf49b94cfe881 fdaa678efa537/en-gb/pdfs/stm200620070024000en_pdfs.pdf, (25.02.2019).

Norwegian Ministry of Finance. (2013). The Management of the Government Pension Fund in 2013, https://www.regjeringen.no/contentassets/5434cb3d2ff04441a21a2 c9b1d55ea06/en-gb/pdfs/stm201320140019000engpdfs.pdf, (23.05.2020).

Norwegian Ministry of Finance. (2014). The Management of the Government Pension Fund in 2014, https://www.regjeringen.no/contentassets/48bb4314d6f14d23aff 45960dc3eaace/en-gb/pdfs/stm201420150021000engpdfs.pdf, (25.02.2019).

Norwegian Ministry of Finance. (2017). Adherence of the Government Pension Fund Global (GPFG) to the Santiago principles, https://www.regjeringen.no/glob alassets/upload/fin/statens-pensjonsfond/gapp/2017_gapp_adherence_gpfg.pdf, (21.05.2020). 
Norwegian Ministry of Finance. (2018). The Government Pension Fund 2018, https://www.regjeringen.no/contentassets/569f03a08ee74350b3778fdbb24dd406 /en-gb/pdfs/stm201720180013000engpdfs.pdf, (25.02.2019).

Norwegian Ministry of Finance. (2019a). Management mandate for the Government Pension Fund Global, https://www.regjeringen.no/contentassets/9d68c55c272 c41e99f0bf45d24397d8c/gpfg-management-mandate-30.11.2019.pdf, (21.05.2020).

Norwegian Ministry of Finance. (2019b). Report to the Storting, https://www.regjeringen.no/contentassets/8996cca30e5741a788218d417762a52c /en-gb/pdfs/stm201820190020000engpdfs.pdf, (21.05.2020).

Norwegian Ministry of Finance. (2019c). The Norwegian Fiscal Policy Framework, https://www.regjeringen.no/en/topics/the-economy/economic-policy/economicpolicy/id418083/, (25.02.2019).

Norwegian Ministry of Finance. (2020). Governance Framework, https://www.regjeringen.no/en/topics/the-economy/the-government-pensionfund/government-pension-fund-global-gpfg/governance-framework-for-thegovernment-/id696848/, (18.05.2020)

Özgül, H. B. (2018). "Varlık Fonları ve Türkiye Varlık Fonu”, Yüksek Lisans Tezi, Marmara Üniversitesi Sosyal Bilimler Enstitüsü, İstanbul.

Peterson Institute for International Economics. (2016). Policy Brief, https://www.piie.com/publications/policy-briefs/uneven-progress-sovereignwealth-fund-transparency-and-accountability, (19.05.2020).

Petoro. (2020). https://www.petoro.no/about-petoro/sdfi-facts, (23.05.2020).

Ping, X. \& Chao C. (2009). "The Theoretical Logic of Sovereign Wealth Funds", https://papers.ssrn.com/sol3/papers.cfm?abstract_id=1420618, (25.02.2019)

Regulation on the financial reporting of Norges Bank. (2017). https://www.regjeringen.no/globalassets/upload/fin/statens-pensjonsfond/ formelt-grunnlag/regulation_financial_reporting_norges_bank_9.march.2017.pdf, (21.05.2020).

Selçuk, M. \& Savaşan, F. (2017). "Türkiye Varlık Fonu ve İslami Finans Alanına Muhtemel Etkileri", International Congress on Politic, Economic and Social Studies, 2.

Skancke, M. (2003). "Fiscal Policy and Petroleum Fund Management in Norway", Fiscal Policy Formulation and Implementation in Oil-Producing Countries, (Ed.) Davis, J.M., Ossowski, R., and Fedilino, A., Washington D.C., International Monetary Fund, 316-338.

Statistics Norway, https://www.ssb.no/en/befolkning/statistikker/folkemengde (19.05.2020).

Sun, X., Li, J. Wang, Y. and W.Clark, W. (2014). "China's Sovereign Wealth Fund Investments in Overseas Energy: The Energy Security Perspective", Energy Policy, $65,654-661$. 
SWFI Institute. (2020a). Sovereign Wealth Fund Rankings, https://www. swfinstitute.org/sovereign-wealth-fund-rankings/, (18.05.2020).

SWFI Institute. (2020b). LMT Index, https://www.swfinstitute.org/research/ linaburg-maduell-transparency-index, (19.05.2020).

Şanlı, U. (2010). “Körfezin "Görünmeyen Eller”i: Ulusal Varlık Fonları”, Ortadoğu Analiz, 2(23), 18-24.

Şimşek, O. (2017). “Çin Yatırım Şirketi Özelinde Finansal Küreselleşmede Devlet Sermayesi: Ulusal Varlık Fonları", Fiscaoeconomia, 1(1), 58- 76.

The Supervisory Council. (2020). https://www.norges-bank.no/en/topics/about /Organisation/The-Supervisory-Council/, (21.05.2020).

Truman, E. M. (2007). Sovereign Wealth Funds: The Need for Greater Transparency and Accountability, Peterson Institute Policy Brief, 07-6.

Truman, E.W. (2009). "A Blueprint for Sovereign Wealth Fund Best Practices", Revue d'Économie Financière, 429-451.

Truman, E.W. (2010). Sovereign Wealth Funds: Threat or Salvation, Peterson Institute, Washington.

TVF Faaliyet Raporu, https://www.tvf.com.tr/uploads/file/tvf-faaliyet-raporu-2017.pdf, (26.06.2020).

Uysal Şahin, Ö. (2017). "Kamu Maliyesi-Varlık Fonu İlişkisi: Türkiye İçin Fırsat Mı Tehdit Mi?", Journal of Awareness, 2, 349-379.

Wirth, E. \& Ramirez- Cendrero, J. M. (2016). "Fiscal Policy And Sovereign Wealth Funds In Oil-Rich Economies: The Norwegian Case", XVIII Reunión de Economía Mundial Conference.

Wirth, E. (2018). "The Norwegian Government Pension Fund Global, Corporate Social Responsibility And Climate Change", Revista De Economía Mundial, No:48, 179189.

World Bank, Population Data, https://data.worldbank.org/indicator/SP.POP .TOTL, (19.05.2020)

Yalçıner, K. \& Sürekli, A. M. (2015). “Ekonominin Çeşitlendirilmesinin Bir Aracı Olarak Ulusal Refah Fonu Modelinin Türkiye Ekonomisi Açısından Uygulanabilirliği", Gazi Üniversitesi iktisadi ve Idari Bilimler Fakültesi Dergisi,17(3), 1-29.

Yazıcı, R. (2017). “Türkiye'deki KiT’lerin Özelleştirme Tecrübelerinden Varlık Fonu Kurulmasına Bakış", Journal of Strategic Research in Social Science, 3(3), 89-100.

Yereli, A. B. \& Yaman, I. (2017). "Ulusal Varlık Fonlarını Anlamak: Fırsat Mı, Tehdit Mi?", Sosyoekonomi Dergisi, 25(34), 69-86. 